\title{
CHERNEL ISTVÁN NAPLÓJA NYUGAT-EURÓPAI UTAZÁSÁRÓL, 1891. AUGUSZTUS 7-30.
}

\author{
Közreadja \\ Faragó Sándor \\ Nyugat-magyarországi Egyetem, Vadgazdálkodási és Gerinces Állattani Intézet \\ University of West-Hungary, Institute of Wildlife Management and Vertebrate Zoology \\ H-9400 Sopron, Ady Endre u. 5., Hungary
}

\begin{abstract}
FARAGÓ, S.: ISTVÁn CHERNEL's DIARY OF WESTERn EUROPE TRIP IN 7-30. AUGUST 1891. Hungarian Small Game Bulletin 12: 1-32. http://dx.doi.org/10.17243/mavk.2014.001

ISTVÁN CHERNEL - the second director (1916-1922) of the Hungarian Institute of Ornithology - in 1891, after his research trip to Norway, he visited the greatest bird collections of European museums in order to make a comparative study of European bird species. This way he went to the Institut Royal des Sciences Naturelles de Belgique in Brussels, then to the British Museum (Kensington Museum) in London and later to the Muséum National d'Histoire Naturelle, Paris. His host was in London RICHARD BOWDLER SHARPE, curator of the bird collection and he also met WILLIAM ROBERT OGILVIE-GRANT (who followed SHARPE in leadership) and also the German ornithologist, who was doing research work there, ERNST JOHANN OTTO HARTERT. Some months before that, all three scientists took part in the 2nd International Ornithological Congress in Budapest, whose general secretary was ISTVÁN CHERNEL. Their professional relations became later friendly as well, and it remained in the long run and the professional results of the journey were recorded later in CHERNEL's technical books.
\end{abstract}

KULCSSZAVAK: CHERNEL ISTVÁN, napló, nyugat-európai utazás KEY WORDS: ISTVÁN CHERNEL, diary, Western Europe trip

\section{BEVEZETÉS}

Chernelházi CHERnEL ISTVÁN (1865-1922) kőszegi születésű ornitológus, a Magyar Ornithológiai Központnak az alapító HERMAN OTTÓ utáni második igazgatója, 1891. június 5. és augusztus 30. között ifjú feleségével, ROTTH DORÁval megtett észak- és nyugat-európai utazásának naplói a Magyar Nemzeti Levéltár Vas Megyei Levéltárában, Szombathelyen találhatók (XIII-5 chernelházi CHERNEL család iratai, 2. doboz. chernelházi CHERNEL ISTVÁN iratai). A 369 oldalon megörökített (1. ábra) történések jelentős része elérhető az érdeklődők számára, hiszen az augusztus 7-ével zárult skandináv útjának leírását CHERNEL ISTVÁN 1893ban már közzétette „Utazás Norvégia végvidékére” címü, saját kiadású könyvében, 449 oldalon, 57 eredeti képmelléklettel (1. ábra) (CHERNEL, 1893). Az utazás hátralévő részében Németország, Belgium, Anglia és Franciaország volt úti céljuk, ahonnan Svájcon és Ausztrián át tértek haza Köszegre.

Elöször is az utazás motivációit kell megértenünk, hogy annak állomásaival is tisztában legyünk. Bár az idézett mü (CHERNEL, 1893) Bekezdö-jében az utazást a ritka vándormadarak északi költőhelyeinek felkeresésével, valamint HERMAN OTTÓ elbeszéléseinek inspiráló hatásával magyarázta, a történeti hátteret illetően egyfajta korábban meghiúsult álomutazásként élte meg CHERNEL.

CHERNEL ISTVÁN - akit atyja CHERnEL KÁLMÁN a jogi tanulmányok után közigazgatási pályára szánt - kora ifjúsága óta a természettudományokhoz, különösen a madártanhoz vonzódott. Ezt segítette - a korszellemnek megfelelően - vadászati érdeklődése is. 1887 öszén érte életében az addigi legnagyobb szakmai megerősítés, amikor unokatestvére, 
MesZleny Lajos megismertette HeRMan OtTóval. Tudni kell, hogy HeRman OtTó 18631864 között (tehát CHERNEL ISTVÁN születése előtt) WAGNER JózSEF besztercebányai fényképésszel mütermet nyitottak és tartottak fenn Kőszegen. Ekkor ismerkedett meg HERMAN CHERNEL KÁLMÁNnal, aki 1864-ben beajánlotta őt BRASSAI SÁmUEL múzeumigazgatónál, az Erdélyi Múzeum-Egylet konzervátori álláshelyére. Ily módon CHERNEL KÁLMÁN volt HERMAN OTTÓ szakmai pályára állásának istápolója.

HERMAN OTTÓt a találkozás során - kőszegi távozása után 23 évvel - olyannyira meggyőzte a 22 esztendős CHERNEL ISTVÁN addigi már nyilvánvaló tudományos teljesítménye, tudása, szakmai elkötelezettsége, hogy azonnal levéllel fordult CHERNEL KÁLMÁNhoz, hogy engedje el vele fiát Norvégiába, a madárhegyeket tanulmányozni. Az atya azonban hajthatatlan volt, CHERNEL ISTVÁNnak előbb a jogi tanulmányait kellett befejeznie. HERMAN OTTÓ útjára 1888 nyarán került sor (HERMAN, 1893).

1891-ben valósulhatott meg CHERNEL ISTVÁN - a jogi tanulmányok miatt meghiúsult, eredetileg HERMAN OTTÓval tervezett - norvégiai utazása. A nagyon jól szervezett úton HERMAN OTTótól ajánlóleveleket is kaptak - mindenre kiterjedt figyelmük, s jelentős anyaggal (39 preparált madár, 1 emlős, 34 kagylófaj több mint ezer példánya, 35 madártojás, 44 növényfaj préselt példányai, 43 néprajzi tárgy, fotók) érkezhettek haza (CsABA, 1963).

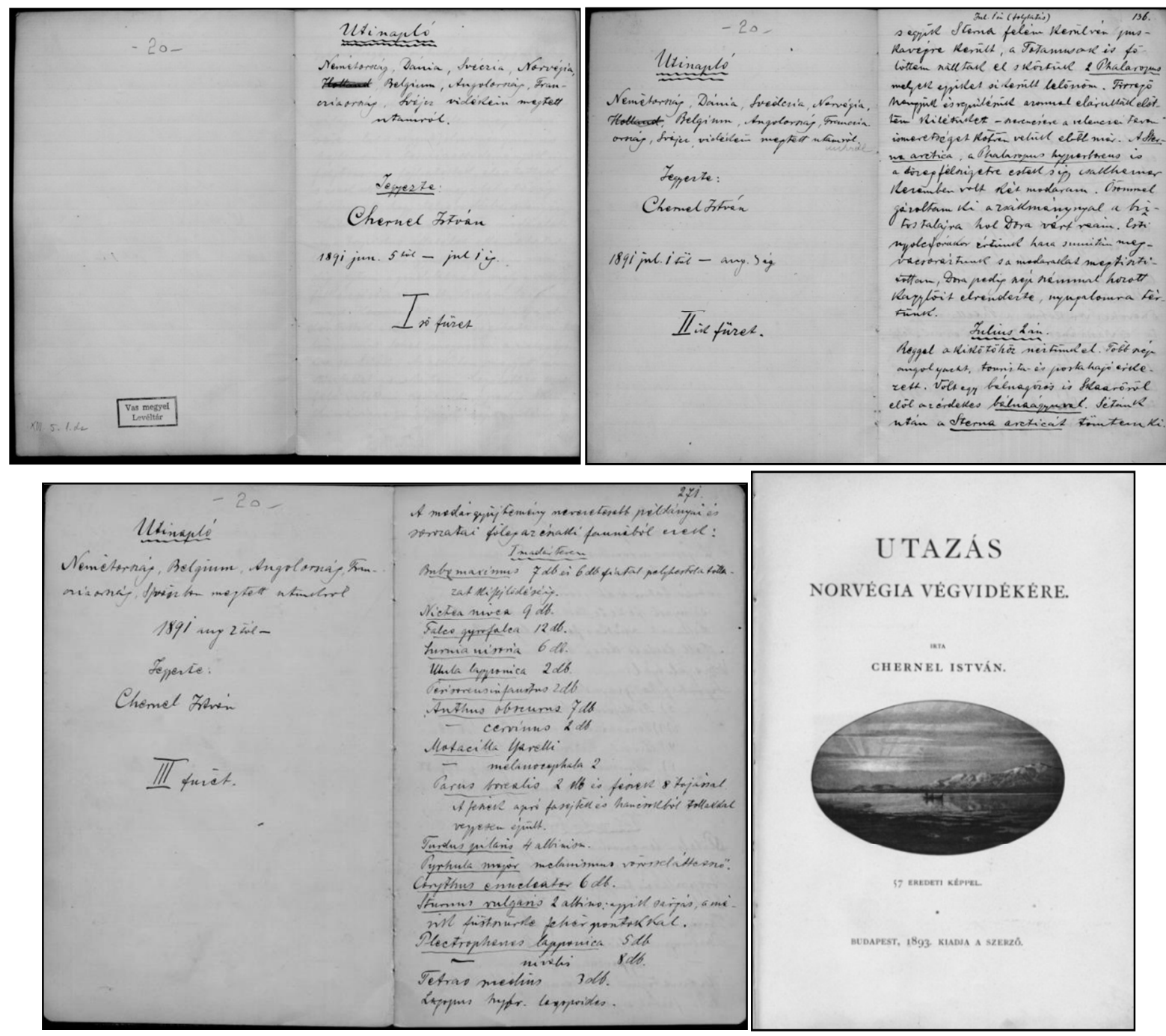

1. ábra: CHERNEL ISTVÁN három naplófüzetének és Norvégiáról írt könyvének címlapja

Figure 1: Covers of diaries and Norwegian book of ISTVÁN CHERNEL 


\section{ANYAG ÉS MÓDSZER}

„Utoljára a kapitánynak kezét ráztam meg, érzékenyen váltunk el, mintha sejtettük volna, hogy ez életben utólszor találkozunk. Ö volt az utolsó norvég, kinek Istenhozzádot mondtunk. Hamburgban két napig pihentünk, ha ugyan pihenésnek lehet nevezni azt az ögyelgést, mely képtárból az állatkertbe, a templomokból a botanikai kertbe stb. viszi az embert.

Elutazásunkat aug. 9-ének estéjére határoztuk, s pedig a czél még mindig nem a „haza felé" volt, hanem Brüssel, London, majd Páris, Svájcz." - olvashatók CHERNEL (1893) utolsó gondolatai könyvének zárófejezetében a norvég utazás lezártával.

A mintegy húsznapos körutazás igazolja CHERNELék széles müveltségét, a müvészetek és a történelem iránti affinitását, nemkülönben szakmai, a természettudományok iránti kiemelkedő érdeklődését. Ilyen jellegü utazást abban a korban csak kevesek engedhettek meg maguknak, különösen akkor, ha annak tudományos aspektusait tekintjük.

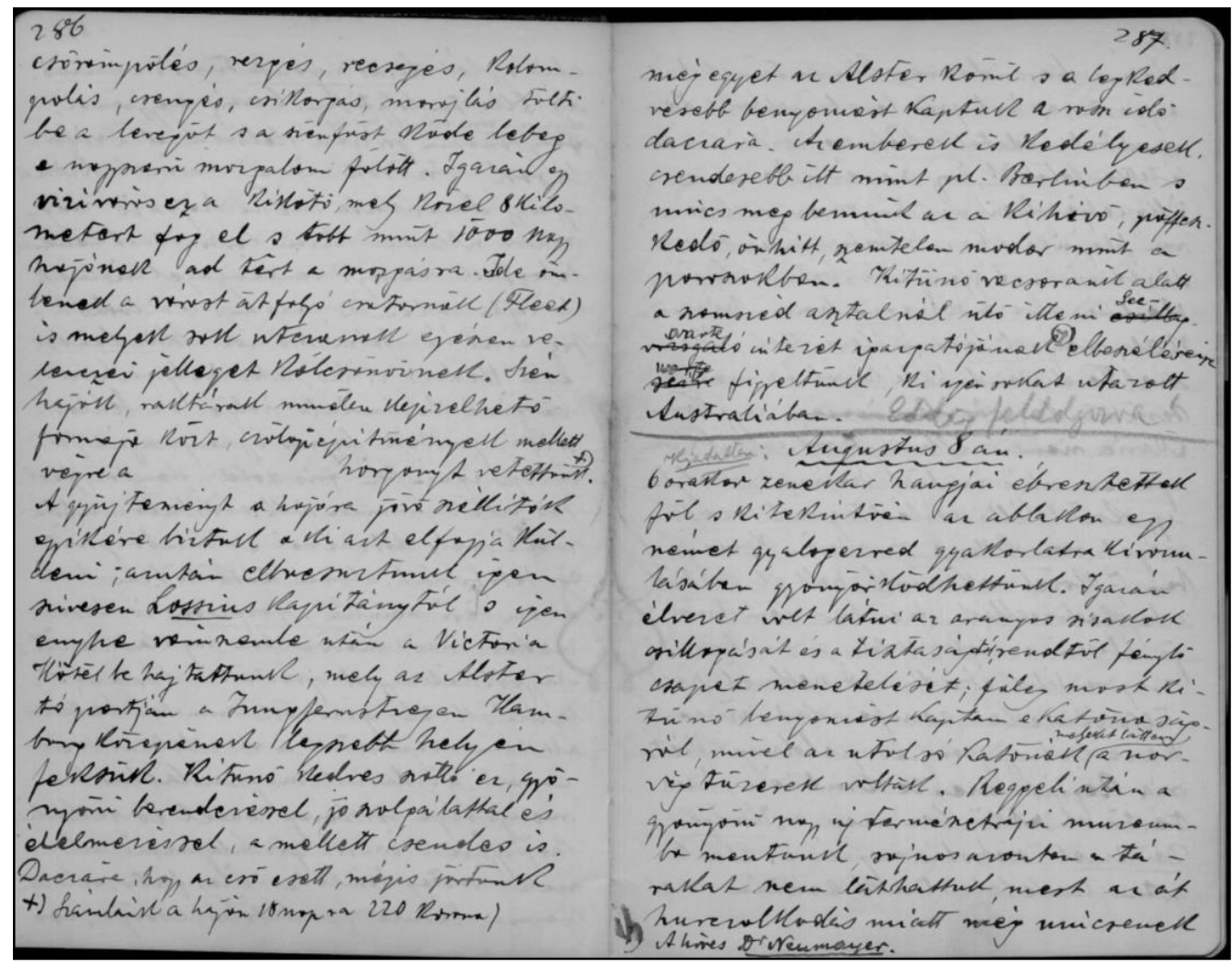

2. ábra: A napló augusztus 7-i bejegyzés végén: „Eddig feldolgozva!”

Figure 2: At the end of 7th August's registration: ,the text has been processed"

Jelen munkában a napló 1891. augusztus 7-30. közötti feljegyzéseit tesszük közzé oly módon, hogy a szöveget betűhíven mutatjuk be, de annak érthetősége kedvéért a mondatokat, gondolatokat tagoló - esetlegesen elmaradt - vesszőket kitettük. Ugyanezt tesszük a hosszú magánhangzók esetében (kivéve felesége nevét, akit következetesen DoRÁnak írt). Amennyiben a nevekben elírás történt, akkor azt [ ] között javítottuk.

A madárfajok latin neveinek meghatározásához, illetve magyar megfelelöjük megadásához a CHERNEL ISTVÁN által 1898-ban összeállított „Nomenclator avium Regni Hungariae" fajlistát (mely nagyon sok szinonimát is tartalmaz) (MAGYAR ORNITOLOGIAI KÖZPONT, 1898), illetve a jelenleg érvényes névjegyzéket (MME NOMENCLATOR BIZOTTSÁG, 2008) alkalmaztam. 


\section{A NAPLÓ}

\section{Utinapló}

Németország, Belgium, Angolország, Francziaország, Svájczban megtett utunkról

1891 aug 2töl-

Jegyezte:

\section{Chernel IstVÁN}

III füzet

\section{Augusztus 7-én}

Hajnalban hagytuk el Helgolandot, mely azonban a nagy hullámzásban és borultságban nem látszott. Ezentúl a tenger csendesebb lőn, s Cuxhavent megkerülve bejutottunk az Elba torkolatába. A víz sárgás, piszkosas, széles, elömlö, helyenként szigetes, nádas, mocsaras. Itt már a Sterna fluviatilis ${ }^{l}$ százai fogadtak és repkedtek hajónk körül, alig egy két Larus argentatus és canus. Az Elba torkolatában 6 óráig megyünk, elhagyva a vörös világító hajókat, folytonosan jönnek, mennek itt a vitorlások, gőzösök igazán százával. Láttunk egy nagy Amerikába menő hajót is megrakva utassal, kivándorlóval. A kendők lobogtak, mennyi reménnyel indult el rajta sok ember, mennyi csalódás fog érni!! Balra marad Blankenese ez a kedves, villás, kertes hely, a hamburgiak kiránduló helye, s a Schleswigi partok lapos egyhangúságát felváltja igazában friss zöld, dombos, fásított vidék, mindinkább erösbülő culturával, mely Altonánál és Hamburgnál éri tetőfokát, olyan kikötőben, hol az emberi munka, forgalom és kereskedés óriási mérvekben nyilatkozik. Nagyobbnál nagyobb gőzösök, vitorlások, ladikok, kis gőzösök minden létező alakban népesítik a vizeket, árbócz erdők, gőzdaruk megszámlálhatatlan mennyisége csikorog, emel és rakodik, hajógyárak óriási gőzkalapácsai zubognak, vastag bömbölés, éles fütty, minden hangon lárma, zakatolás, csörgés, csőcsörömpölés, rezgés, recsegés, kolompolás, csikorgás, morajlás tölti be a levegőt, s a szénfüst köde lebeg e nagyszerü mozgalom fölött. Igazán egy viziváros ez a kikötő, mely közel 8 kilométert fog el, s több mint 1000 nagy hajónak ad tért a mozgásra. Ide ömlenek a várost átfolyó csatornák (Fleeb) is, melyek sok utczának egészen velenczei jelleget kölcsönöznek. Szén hajók, raktárak minden képzelhető formája közt czölöpépítmények mellett végre a ....... horgonyt vetettünk (Számlánk a hajón 10 napra 220 korona).

A gyüjteményt a hajóra jövő szállítók egyikére bíztuk, aki azt el fogja küldeni; azután elbúcsúztunk igen szívesen LossiUs kapitánytól, s igen enyhe vámszemle után a Victoria Hotelbe hajtattunk, mely az Alster tó partján a Jungferstiegen, Hamburg közepének legszebb helyén fekszik. Kitűnő kedves szálló ez, gyönyörü berendezéssel, jó szolgálattal és élelmezéssel, amellett csendes is. Daczára, hogy az eső esett, mégis jártunk még egyet az Alster körül, s a legkedvesebb benyomást kaptuk a rossz idő daczára. Az emberek is kedélyesek, csendesebb itt, mint pl. Berlinben, s nincs meg bennük az a kihívó, pöffeszkedő, önhitt, szemtelen modor, mint a poroszokban. Kitűnő vacsoránk alatt a szomszéd asztalnál ülő itteni Seewarte intézet igazgatójának (A híres Dr. NEUMAYER ${ }^{2}$ ) elbeszéléseire figyeltünk, ki igen sokat utazott Australiában.

\footnotetext{
${ }^{1}$ ma Sterna hirundo - küszvágó csér

${ }^{2}$ GeORG VON NeUMAYER (1826-1909) - a hamburgi Deutsche Seewarte igazgatója 1875-1903 között
} 


\section{Augusztus 8-án}

6 órakor zenekar hangjai ébresztettek föl, s kitekintvén az ablakon, egy német gyalogezred gyakorlatra kivonulásában gyönyörködhettünk. Igazán élvezet volt látni az aranyos sisakok csillogását és a tisztaságtól, rendtől fénylő csapat menetelését; főleg most kitünő benyomást kaptam a katonaságról, mivel az utolsó katonák, melyeket láttam, a norvég tüzérek voltak. Reggeli után a gyönyörü nagy új természetrajzi múzeumba mentünk, sajnos azonban a tárakat nem láthattuk, mert az áthurczolkodás miatt még nincsenek készre berendezve. Elmentünk hát a postára, hol pár levelünk volt LoRÁNDtól ${ }^{3}$, ADÁtól ${ }^{4}$. Mély szomorúságomra értettem belőlük, hogy szegény BENCZE ${ }^{5}$ állapotja oly súlyos, hogy nem sok remény van felépüléséhez s valószínüleg sorvadásba esik. A gyönyörü botanikai kertben olvastuk végig honi híreinket, melyek bizony levertek; CHERNEL FERDINÁND ${ }^{6}$ haláláról is most értesültünk, vagy DőRY MÁRIA néném elhunytáról is. Az idén igazán alig múlik hónap, melyben egy közel álló családtagunk veszteségét nem kellene siratni. Hamarjában 17 közel rokonunk halt el, köztük a legkedvesebbek. Az ember nem tudja élvezni az életet békén, s minden napra félve ébred. A szebbnél szebb ültetvényeket, coniferakat ${ }^{7}$, üvegházakat, egy pompás példány Victoria Regiát $^{8}$ megtekintvén, hazatértünk, közben még a „Krieger Denkmal” szobrot is megnézve. Ebéd után leveleket írtunk, azután az állatkertbe siettünk. Nagy arányok szerint rendezett kiválóan érdekes hely ez! $\underline{B R E H M}^{9}$ tervei és felfogása szerint van minden elhelyezve és csoportosítva. Kiválóbb pontjai az elefántház, hol több gyönyörü példány mellett víziló és rhinoceros is van, a nagy oroszlánház (szebbnél szebb tigris, leopárd stb), bagolyvár, melynek tornyáról szép kilátást élveztünk, vízesés és tó szép példány pelikánokkal, flamingókkal, kócsag-, gém, ibis- stb. félékkel, a terrarium, aquarium, stb. Visszatérvén néhány bevásárlást végeztünk, majd „Taxonom Droschken” kocsiztunk egyet. Ezek igen jó, elegáns, úri fogatokhoz hasonló egy lovas kocsik (két lovas nincs); a kocsis szép úri kocsis öltönyben, cylinderben. A bakülésben óramü van alkalmazva, mely a megtett utat távolság szerint kifejezi. E távolságmérőn van egy lap, mely 800 métert mutat, s egy másik, mely a 800 métereket fejezi ki egy-egy számban. Ez a praktikus berendezés azután pontosan megmondja a bér nagyságát, $\mathrm{s}$ az utas nincsen kitéve oly kellemetlen túlköveteléseknek, mint Bécsben vagy Budapesten stb. Azon kívül a kocsikon egy kis vasbádog zászló is van alkalmazva a lámpák mellett, melyen ez áll: „Frei”. Ha a kocsi le van foglalva, e zászlócskát visszahajtják, ha pedig szabad, fel van állítva, s rögtön észre vehetö.

Először bejártuk a kikötőt, meglátogattuk még egyszer a „Siriust”, s végleg elbúcsúztunk tőle. Azután a régi sánczok közt kocsiztunk odább, melyek most a legszebb ültetvényekké vannak átalakítva. A sürgő forgó nép közt sok eredeti viseletủ asszony tűnt fel gombaforma szalmakalapban, hátul óriási nagy fekete keresztkötésü szalaggal, hímzett vállfüzővel; rövid szoknyában, kék, piros harisnyában - ezek a „Vierländerek” igazi hamburgi viseletüek. Este a Circus Renzet látogattuk meg, mely tömve volt. A nagyszerü mutatványok közt legeredetibb az a rész volt, mely Helgoland szigetén mutatott be egy jelenetet. A circus belsejét két oldalt hirtelen nagy vízesésekben árasztotta el 150 köbméter víz, jöttek gőzös, hajók, lőnek felfordulások, fürdések - szóval az egész helgolandi élet egy tréfás darabja lejátszódott szemünk előtt.

\footnotetext{
${ }^{3}$ ROTTH LORÁND - CHERNEL ISTVÁNNÉ sz. ROTTH DORA bátyja

${ }^{4}$ ROTTH ADA, férjezett nevén báró MANNSBERG SÁNDORNÉ - CHERNEL ISTVÁNNÉ sz. RoTTH DORA nővére

${ }^{5}$ MESZLENY BENCZE (Velence) - CHERNEL ISTVÁN nagybátyja

${ }^{6}$ CHERNEL FERDINÁND (1815-1891) - vasi alispán, élt Rábahidvégen, CHERNEL IsTVÁN unokabátyja

${ }^{7}$ tülevelüeket

${ }^{8}$ ma Victoria amazonica - amazonasi óriás-tündérrózsa

${ }^{9}$ ALFRED EDMUND BREHM (1829-1884) - német természettudós, 1863-1867 között a hamburgi állatkert igazgatója
} 
A nap folyton esővel váltakozó derült idő közt múlt, de majdnem minden órában volt egy zápor.

\section{Augusztus 9-én}

Délelőtt pár bevásárlást tettünk. Daczára a vasárnapnak, mise után minden bolt nyitva volt. (Norvégiában egy sem, sőt tegnap este 11 órakor is minden nagyobb bolt nyitva állott, ami itt szombaton szokásban van.) Délfelé a ScHILlER szoborral szemközt egy dombon emelkedő Kunsthalleba mentünk, s több óráig időztünk a gyönyörü festmények és szobrok közt. Körülbelül 800 értékes festmény, sok híres rézmetszet, vázlat van itt együtt. Külön kiállítást képez a több teremben elhelyezett, vagy 28 képet felölelö SCHWABE féle alapítvány, mely főleg a modern angol mesterek müveit tartalmazza, s e tekintetben egyetlen a maga nemében egész Európában. Nevezetesebb mesterek, kiknek képeit láttuk: FRANCK, BAKHUIZEN, LOOTEN, KUPETZKY (magyar), MuRILlo (Gyümölcsös fiú), GUIDO RENI (JUDITH) (Maria menybemenetele), SNyders, ZAmpiéri, Burnier, CAlame, DAhl, DEFregGer, Deiker, Len (Jognefjord), MAKART (V. Károly bevonulása Antwerpenbe), MELBYE, MEYERHEIM, MORGEnStern, MÜller-Morten (Norvég fenyőerdő), MunTHe, Oesterley (Norvég vidék), Rechlin, Vogel HugO, CRANACH LuKÁcS (Hagyjátok a kicsinyeket hozzám jönni), Ruysdael, Kröner, Overbeck, Vantier, Vernet Horac[e], Ansdell, Viant Cole, COLIN Hunter, Tidemand. Haza jövőben a merész gothicus tornyú Nicolai [St. Nikolai] templomot néztük meg, mely $174 \mathrm{~m} .{ }^{10}$ magas és egyike Európa legmagasabb épületeinek. Ebéd után írtunk és csomagoltunk, az eső miatt nem lehetett kimenni. Este kissé elhagyta az esőzést s gyönyörü képet élveztünk ablakunkból a kivilágított Alsterokra. Számlánkat kifizetvén (....) a venloi állomásra kocsiztunk. Podgyászunkért Kölnig $11 \mathrm{Mk}^{11}$ fizettem. $\mathrm{Az}$ állomáson ismerős hangok ütötték meg füleinket - 3 magyar beszélgetett egymással - sok idő múlva, daczára, hogy nem valami jeles fiak voltak, jól esett beszédjük füleinknek. 11 órakor indultunk, s a velünk beszállott két utas a szép brémai pályaháznál elhagyván bennünket, kényelmesen aludhattunk. Folytonos eső.

\section{Augusztus 10-én}

Néhány fellobogózott kisebb nagyobb német várost elhagyva, reggel 7 óra felé megpillantottuk az egész vidéket domináló gyönyörü, egyetlen Kölni dóm két égnek emelkedő 156 m magas tornyát, s nemsokára az állomásra értünk, mely e remek templom tőszomszédságában fekszik. A pályaudvaron megreggelizvén, azonnal a dómba siettünk, mely külsőleg, belsőleg befejezett mü, s minden további méltatás mellőzésével, csak azt írom róla, hogy leírhatatlan benyomást tesz a lélekre, s végtelen emelkedett, meghatott hangulatot varázsol a lélekbe, utolérhetetlen fenséges harmóniájával. Ezután egy kis gyalog sétát tettünk a belvárosban, mely csupa szük utczából áll, úgy hogy alig bír két kocsi egymás mellett elmenni, sok utczában pedig egyáltalán csak egy fér el. Hogy minden nevezetességet rövid idő alatt végig járjunk kocsira ültünk, s elöször az Altstadtot jártuk be. Láttunk MOLTKE stb. szobrokat, a szép régi templomokat, városházát, a „két lófejes” épületet, mely régi épületek és templomokhoz kocsisunk egy-egy mondát beszélt el, vagy hozzá füződő történeti eseményt. Később azután kimentünk az új városrészekbe, hol széles utczák, gyönyörü paloták, fasorok, kertek élénk ellentétet képeznek az Altstadt vén házaihoz. Ez az új része Kölnnek, amily érdekes, a régi, oly szép. A régi sánczok egyes tornyai még állanak, s sürü repkény alá

\footnotetext{
${ }^{10}$ valójában $157 \mathrm{~m}$

11 márkát
} 
bújnak, mintha szégyellnék ócskaságukat az új erődítések mellett, melyek a várost körülfogják.

Az Elba parttól folyton erődítések közt haladva majd minden 10 percz után egy Forthoz értünk, hol tátongó ostromágyuk körül tüzérek gyakorolták magukat; átmentünk az új népkerten is, alig egy pár éves, kitünően gondozott parkon, majd a nagy körutakon kocsiztunk végig, melyek kisebb kiadásba a mi sugárutunkhoz hasonlítanak. Egy helyen egy ezred zenekara séta hangversenyét hallgattuk meg, ez a zenekar egész szépen játszott. Elmentünk még egy nagy panorámába is, mely nagy méretekben müvésziesen ábrázolta a Vionvillei és Mars la Touri ütközetet hol a Bredow dandár teljesen feláldoztatott a diadal kedvéért. Délfelé járván a Wallraf Richartz múzeumot néztük még meg, mely valódi kincses ház nagy müvészi becscsel bír, gazdag és értékes. A sok remekmü és nevezetes dolog közül alig lehet a fontosabbakat is kiválasztani, mert 1070 db-on felül van itt kép és szobor. A feljárat lépcsőházat STEINLE tanár freskói díszítik, melyek Köln cultur és müvészettörténetét ábrázolják. A képek további elhelyezése következő terv szerint foganatosíttatott: Régi kölni festőiskola művei a byzanti-román korszakból, góth korszakból, MEISTER WILHELM, MEISTER STEFAN és iskolája, ANTON WORMS; későbbi kölni festők olasz, [német]alföldi és franczia hatás alatt, frank iskola (ALBR. DÜRERtől: egy sipos és dobos, a madonna gyermekkel és még négy kép iskolájából), szász iskola (LUCAS SUNDER nevezve: CRANACH az idősebb), sváb iskola, határozatlan német iskola KUPETZKY, [német]alföldi iskola, ebben RUBENStöl 5 kép, VAN DYCKtól négy kép, DE CRAYERtől 1 kép, ó-olasz mesterek festményei közt TiZIANtól 2 kép, franczia iskola, spanyol iskola, és modern festőiskolák utóbbiban képek következőktől: I. CH. Dahl (norvég), Achenbach, VAntier, Knaus, Kray, Stückelberg, Defregger, SCHWERDGEBURTH, LIEZEN MAYER, BÖHM PÁL (magyar) (magyar halász élet), ANTON vON WERNER stb. Ezután következik egy aquarell gyüjtemény, kartonok (OVERBECK!) rajzok, üvegfestmények, szobrok.

A múzeumból a nagy Elba híd mellett Cook utazási irodájába mentünk, s lebélyegeztetvén jegyeinket az indóházra siettünk, hol megebédelvén 1.15-kor Brüsselbe indultunk, meglehetös tömött kocsiban. Aachen történeti nevezetességü városa mellett elszáguldva Verviersbe értünk, az első belga városba. Itt felületes vámszemle után más kocsiba szálltunk, s (10 egy coupéban!) meglehetős szorosan utaztunk tovább a kedves, szép belga kastélyok mellett, temérdek alagúton át Lüttich ${ }^{12}$ gyáraktól hemzsegő városába majd Louvainbe ${ }^{13}$ folyton gyárakat, falvakat hagyogatva el, mígnem 1/27-kor Brüsselt elértük. Hotel de Flandreba szálltunk, s itt is, mint Hamburgban, kényelmes felszállón ${ }^{14}$ érkeztünk 2-ik emeleti szobánkba. Miután elhelyezkedtünk, 7 fogásos ebédet ettünk (á 6 fr) azután lefeküdtünk.

\section{$\underline{\text { Augusztus 11-én }}$}

Reggeli után kocsira ültünk, s várost tekintettük meg. Gyönyörü egyenes utczák, nagyszerü paloták mindenfelé! Az építkezés tekintetében magas fejlettség és pazarlás. Megnéztük a Congres szobrot $^{15}$, azután a nagyszerü, hatalmas igazságügyi palotát, hol egy bírói tárgyaláson is részt vettünk. A bírák hivatalos fekete tógában fehér gallérral ültek emelvényükön, s a vádlottak szomorú padja mögött 4 medvebőr süveges gránátos feltüzött bajonettal őrizte a lopással vádlott bünösöket. Mindenki szabadon jár itt be-ki, s a nyilvánosságnak legnagyobb mérvben elég van téve az igazságszolgáltatásnál. Elmentünk

\footnotetext{
12 Liège német neve

${ }^{13}$ Leuven francia (flamand) neve

14 liften

${ }^{15}$ Colonne du Congrés
} 
aztán a dómba, miután az igazságügyi palota elöl, mely dombon fekszik, az egész városra eső kilátást élveztuik. A dóm olyanforma, mint a kölni, csakhogy két nagy tornya nincs kiépítve, s egy harmad is hiányzik belőle. Hatalmas benyomást kaptunk e remekmü belsejében, melynek kincsei közt kiemelkedik a müvésziesen faragott fa szószék felejthetetlen alakja. A dómból az első brüsseli csipke raktárba mentünk, s megmutogattattuk magunknak a csipke készítés módját. Láttuk boldogult trónörökösünk nejének, STEFÁNIA trónörökösné öfenségének menyasszonyi fátyol mustrázatát. A fátyol itt készült, s 6 hétig 400 asszony dolgozott rajta. Gyönyörü csipke dolgokat mutattak ezután, s emlékül vettünk egy szép zsebkendőt (18 frk). Kocsink ismét a királyi várhoz, s a mellette vonuló egyenes óriási vén fasorokkal beültetett egyenes ...... végig vezetett, majd a kir. színház, az aristokraták utczáján át a természetrajzi múzeumban szálltunk le. Egészen új épület ez, még nincsen teljesen elkészülve, de belseje már berendezett. Az épület L alakú, s az alsó terem magasságban két részre osztott úgy, hogy a fölső része körfolyosókból áll, hol a madarak vannak elhelyezve és pedig teljesen üveg szekrényekben, melyek közepe deszka fallal van elválasztva úgy, hogy tulajdonképpen kettős szekrények vannak.

$\mathrm{Az}$ alsó részben vannak ásatag dolgok és emlösök, s az egész termet uralja a négy felállított óriási Iguanodon bernissartensis példány, melyeket Belgiumban ástak ki. Az ötödik szintén óriási példány nincs felállítva, hanem eredetileg úgy fekszik felborítva, mint találtatott. Ezek után e terem neve is „Bernisartensis terem”, s e példányok világhírüvé tették a brüsseli múzeumot. Kiválik még egy szintén óriási Balaena mysticetus ${ }^{16}$ csontváz. A madárgyüjtemény következő tért fogja el: 4 szekrény madárcsontváz, 4 szekrény belga madár (1-ső emeleten), s 58 szekrény az általános madárgyüjtemény (11/1/2 szekrény ragadozók, 6 szekr. gémfélék, 3 szekr. szalonkák, túzokok, tyúkok, 51⁄2 szekr. úszók, 1 szekr. futók, 2 szekr. papagáj, 29 szekrény varjak, éneklők, harkályok, galambok stb.

Üvegbura alatt van egy kitömött $\underline{\text { Alca impennis }}{ }^{17}$, e kihalt faj, s néhány csontja. Lusciniola melanopogon $^{18}$ van 2 pld. Toscanából, 1 pl. Volga torkolatból. (A dán példány Acr. phragmitisek ${ }^{19}$ színe a miénkhez hasonló, de barnásabb). A belga madarak közt feltünt Anthus cervinus és fészke 4 tojással Oroszországból! Mindenütt, ha talán a fajnál hiányzik, a családoknál ott van egy apró kis térkép az egész földről, s a faj vagy család földrajzi elterjedése ki van színezve. Az őrök mind frakkban ülnek a termekben, s mindenütt a legnagyobb rend uralkodik. Van egy egész emelet Belgiumban talált ásatag állatokkal, s ezek közt a világhírü mamuth példány, melyet Liérreben találtak. A legfölsőbb emeleten 6 sorban felállított szekrényben ismét paleontológiai és geológiai, mineralógia gyüjtemény teszi. Egyáltalán a paleontológia dominál az egész múzeumban.

A múzeumból a ministeri paloták mellett haladtunk a boriehez és a boulevardokra. A ministeri paloták egy egész utczát képeznek, s mind egymás mellett vannak. Az utczára eső homlokzatuk földszintes, s az udvart három oldalt befogó hátsó részeik több emeletüek - ha a mi földmívelési ministeriumunk épületére gondolok, hát a különbség az, hogy ezek igazán ministeri paloták a legízlésesebb és praktikusabb építkezésben, az pedig ministeri kaszárnya, a leginpraktikusabb, ízléstelen kivitelben. Brüsselben szépen és jól tudnak építeni! Még a börzét, az új és ó postaépületet tekintettük meg, azután hazatértünk, s 4 fogásos déjeunerhez ${ }^{20}$ ültünk (á 4 frk). Délután ismét a városba sétáltunk, bevásárlásokat végeztünk, majd kocsin a boulevardok életét néztük meg. A hordárok itt hálóingforma fehér hosszú köntöst viselnek ruhájuk fölött, s számuk karjukra erősített fém táblácskán van. A katonaság egyenruházata

\footnotetext{
${ }^{16}$ grönlandi bálna

17 ma Penguinus impennis - óriásalka

${ }^{18}$ ma Acrocephalus melanopogon - fülemülesitke

${ }^{19}$ ma Acrocephalus schoenobaenus - foltos nádiposzáta

20 ebédhez
} 
egész csinos és amily praktikus, annál jobban még fényes is. Vállrojtok, zsinórzat, aranyozás, karszalagok dúsan vannak egyenruhájukon. Sapkájuk vagy csákójuk francziás, csak a vadászoknak van egész külön alakú, csonka kúp alakú zöld sárgarojtos, a lovasoknak pedig összehajtott dánsapkájuk. Nadrágjukon oldalszalagok, sávok vannak hol piros, fehér, vagy sárga. Igen jól néznek ki a nagy medvebőr fövegü gránátosok és az elegáns dzsidások, bíborvörös nadrágú zöld sávos, zöld dolmányon fekete zsinóros lovasok. Kocsikázásunk közben egy éppen zeneszóval megérkező vadászezredet láttunk, s igen kedvező benyomást kaptunk a csapat fegyelméröl is. 5 órakor a kép és szobor tárt látogattuk meg, hol több mint 50 RUBENS képet (Íme az ige stb.), VAN DYCK leghíresebb képét bámultuk meg. 8 órakor 7 fogásos ebédünket elköltvén írásainkat végeztük és csomagoltunk. Nagyjában szép idő, de eső is; meleg.

\section{$\underline{\text { Augusztus 12-én }}$}

Reggel csomagolásunkat befejeztük, azután számlánkat fizettem ki (71 frk). Vettem még néhány belga levéljegyet ${ }^{21}$ is, emlékül álljanak itt. (Brüsszelben még több Cypselust ${ }^{22}$ láttam).

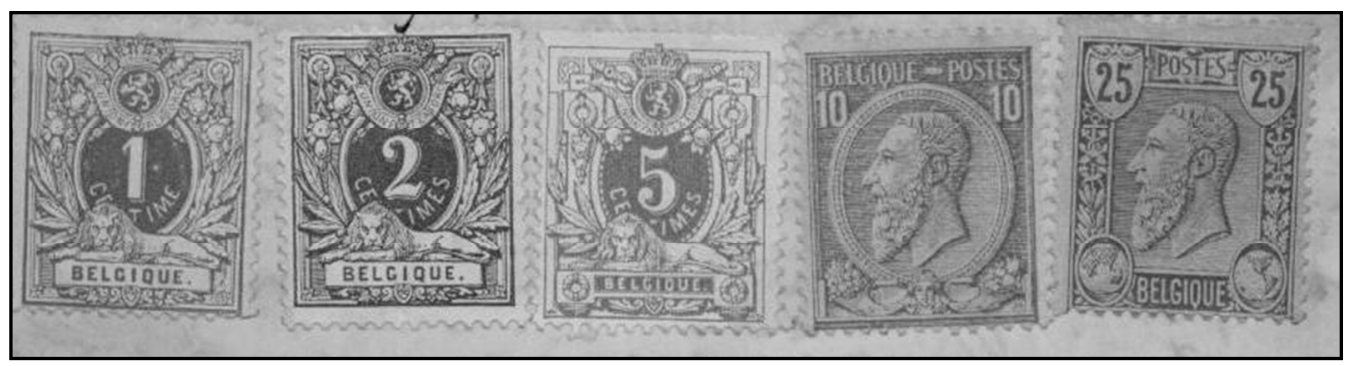

9 órakor a vasúti állomásra hajtattunk ott már Hotelünk egyenruhás embere várt, ki podgyászunkat feltette a vasúti kocsira s a nagy málha feladásánál segédkezett, a mi a temérdek utas, málha és élénk forgalomban nagyon kellemesen esett. Az express vonat ezután sebes iramlásban vitt ismét északnak, a kedves vidékről azonban e gyors futás közt, de meg a borult esős világosságszűk időben nem igen láttunk mást, mint a szélmalmokat és parkokat. Gand $^{23}$ városát elhagyva 11 órakor értünk Ostendebe, melynek magas világító tornyát előbb már megpillantottuk. Közvetlen a vonat mellett várt a nagy, kétkéményes, több emeletü „, $\underline{L a}$ ville Dover" belga kerekes gőzös, melyre átszálltunk, s a hajó közepén foglaltunk helyet, az alsó fedélzeten. Nem sokára mozgásba jöttek a kerekek s újra elterült előttünk a végtelen tenger, mögöttünk maradt Ostende partja, tengerre néző nagy házsora és a parton álló száz meg száz vászon fürdőház, melyek közt fekete pontokként, mint a hangyák, a fürdő vendégek alakjai mozogtak. Meglehetős erősen fújdogált az északnyugati szél, s így egy órai csendes utazás után újra éreztük a hajó erős himbálását, mely ezentúl folyton erősbült, $\mathrm{s}$ a hullámok a hajó orrán majdnem a középfedélzetig csapkodtak. Hamarosan jó drágán megebédeltünk, de járkálásról szó sem lehetett $\mathrm{s}$ csendesen meg kellett magunkat védett helyünkön húzni, nehogy a becsapkodó hullámok végig mossanak. Az eső ugyan elállott, sőt a belga partok eltüntével az ég is kitisztult, de a szél nem csendesült le. A nagy hajó pedig belevágta orrát a tengerbe, aztán meg felcsapta a magasba; a himbálkozás ugyancsak erős lőn. A legtöbb utast megkapta a tengeri betegség, hol egyik, hol a másik kezdett halaványodni, sokan győzködtek jó ideig, de végre is erősebb volt a megémelyítő mozgás, s nem kerülhették el sorsukat.

\footnotetext{
${ }^{21}$ bélyeget

22 ma Apus - sarlósfecske

23 : Gent
} 
Gyermekek, öregek, asszonyok, férfiak siettek a karfákhoz, hordozták a félelmetes, sokuknak a gyülölet netovábbját képező bádog lavórokat. Csak a matrózok mosolyogtak gúnyosan e felfordult világnak, szegényeknek ilyen az egyedüli mulatságuk! DoRA nem mert mozdulni székéről, mert kissé szédelgett, de én rajtam nem fogott a tenger hullámzása, s fel sem vettem, egy cseppet sem éreztem magamat másként, mint a szárazon. A szél folyton dobálta a hajót, a rosszul levők mindig szaporodtak, s még akkor sem állt be csillapodás, mikor Anglia partjai megjelentek. Csak mikor a fehér kréta sziklák teljesen kivehetők voltak már, így Dover városa és erössége megjelent, s már-már a kikötőbe értünk, lőn békésebb hullámjárás. A nap reásütött a fehér partra, melyet sok jövő menő nagy vitorlás és gőzös élénkített, az erősség ágyúi pedig eldördültek, mikor hajónk megállott és horgonyt vetett. Kézi podgyászunkat a hajón vizsgálták át, s minthogy a férfiakét igen tüzetes szemle alá vetették, összes málhánkat DORA magáénak adta ki, s így hamar megszabadultunk e kellemetlen feltartóztatástól. Sok férfi táskából csak szó nélkül vándoroltak a szemlések kezei közé a tilos dolgok; mindenesetre itt erős vizsgálat éri az embert. A Victoria állomásra menő vonatba szállván csakhamar szédítő sebességgel rohantunk az angol fövárosnak, s daczára az őrületes sebességnek mégis jól éreztük magunkat a 4 órai tengeri út után, mert az angol vonatok nem ráznak. A kocsik tágasak, 6 ülésűek, kényelmesek, de a nagy forgalom következtében nem tiszták és kellemetlen levegőjüek. Jegyünket mindjárt beszállásnál elvették, s többet a kalauzt nem is láttuk. Egy pár alagút után kibontakozott az igazi angol vidék parkszerü képe, a kedves repkényes cottagek ${ }^{24}$, templomok, a parkokban legelő nagy juhok, lovasok, tennis játszók, sürü komlós kertek, melyek virágait a kert köré éppen a virág magasságában húzott leplek védik a széltől, s megláttuk a távolabbi tájak fölött kéklő ködszerü fátyolt is. Egy pár kisebb nagyobb hely csakúgy elfutott mintegy vonatunk mellett, egyik alagútba be, másikból kifutottunk szinte bújókat játszva még nem beértünk London elővárosaiba, s az utczák közt jó ideig robogva $1 / 26$ órakor a nagy Victoria Állomásra. A forgalom iszonyú nagy mindenfelé, $\mathrm{s}$ akkoriban körülbelül 10 vonat sustorgott el mellettünk, éppen csak mintegy pattanás. Az állomáson MAY és a szép HELEN vártak, s igen szívesen fogadtak. Málhánkat alig nézték meg, éppen csak belepillantottak egyikbe. Egy négy személyre való omnibus forma kocsit foglaltunk el, s rövid hajtás után Blomfield Crescent 4. 20. alatt szálltunk le. Az angol lakások kényelmes berendezése mindjárt feltünt. Itt az emberek alulról felfelé laknak, minden félnek külön háza van, s nem is érintkezhetik a házban idegen lakóféllel. A szobák egymás fölött vannak, nem egymás mellett, kapu nincs a házon, csak ajtó, s kocsi nem járhat be. Legalul van a konyha, e fölött az ebédlő, e fölött a nappali szobák, azután a hálószobák, s legfelül a cselédszobák, a dohányzó az ebédlő mögött van.

Az ablakok üvegház szerüen majdnem egy egész oldalt fognak el, s fel alá tolható táblák által nyithatók, zárhatók. A világítás gáz, vízvezeték szolgál mindenüvé, van fürdőszoba meleg és hideg vízcsappal, kézmosóhely, a melegítésre kandallók. Miután betelepedtünk szobánkba, s elrendezgettük holminkat, 7 órakor megszólalt az ebédre hívó harang, tehát ebédhez ültünk, mely állott halból, egy marhaczombból, puddingból, s kitünő theából. Ebéd után még sokáig beszélgettünk, s 11kor tértünk nyugalomra.

\section{$\underline{\text { Augusztus 13-án }}$}

Fürdő és reggeli után MAY kilovagolt a Hyde parkba, mi meg HELENnel bevásárolni mentünk a híres Whitely házba. Ez egy óriási telep, több ház két emeletben összesítve nagy csarnokokkal, hol a gondolható mindenféle bolt együtt van, s mindent amire csak gondolni lehet, amit kívánhatunk olcsón, kitünően nagy választékban meg lehet kapni, czukrászat,

\footnotetext{
${ }^{24}$ házikók
} 
bőrkereskedés, szőrbolt, pénzváltó, játék, porczelán, ruha, czipő, czukrász, étkezö, minden minden van itt, a legpraktikusabban berendezve, a világ minden fajta áruja és kívánalma, terménye egy födél alatt, külön kisebb részekben. Egy óriási labyrinth ez, óriási forgalommal, amiről alig lehet annak fogalma, aki nem látta. Ilyen ház még sok van Londonban! Daczára hogy a seasonnak már régen vége van, s egész utczák kihaltak, egész házsorok függönyei le vannak bocsájtva, a forgalom minden nagyobb utczában óriási, amennyi ember Budapesten az utczákat népesíti, itt ugyanennyi csak a kocsi és jármü. A sokemeletes omnibus, az egy fogatú bérkocsi, melynek bakja a kocsitető mögött van, egészen sajátos képet nyújt. A reklám pedig lépten nyomon hihetetlen furfangokban nyilvánul és lep meg. Már utunkon Dovertől az egész vasútvonal mellett kísértett százával fehér táblákra festett barna körök rajta fehér betükkel Tear soap ${ }^{25}$, itt az omnibusok, kövezet csak úgy tarkállik a hirdetések rikító színű felirataitól, bizarr szemcsalogató alakjától. Gyakran 10-20 egymás után menő emberrel találkozunk, kiknek mellén-vállán óriási fehér táblán olvasható egy-egy czég hirdetése. 1 órakor hazatértünk, s dèjeunert ${ }^{26}$ élveztünk, azután kocsin a Regent és Oxford streetek mozgalmas életét néztük meg, majd a Liberty házba mentünk, melyben hihetetlen arányban és ízlésben vannak India kincsei felhalmozva. A Hyde Park hatalmas útjain mentünk azután ismét haza. 5 órakor theáztunk, s ebédig beszélgetés közt múlt az idő, közben HELÉN gyönyörüen énekelt. 7 órakor ebéd. Este norvégiai utunkról beszélgettünk, s magunkkal hozott fényképeinket mutogattuk meg. Szép, meleg idő. Itt az éjjelek, esték és reggelek hűvösek, a nap többnyire meleg. A növényzet, gyep gyönyörü, üde, ami a sok harmatnak elönyös hatása. LOUISE sajnálatunkra nem volt itt, mert két hétre Norvégiába utazott.

\section{Augusztus 14-én}

Reggeli után HELENnel a Kensington parkon át, mely a Hyde parktól csak egy út által van elválasztva, a monumentális Kensington Múzeum természetrajzi gyüjteményeibe mentem, mely gyüjtemény tulajdonképpen a British Múzeumhoz tartozott előbb. 1/21-ig időztem itt, végig nézve hamarjában az egészet, hogy egy általános képet kapjak róla, persze legtöbbet a madarak közt időztem és az ásatag állatok közt. Azt a benyomást és a múzeum leírását is, melyet saját tapasztalatom szerzett, majd csak akkor ismertetem meg bővebben, mikor többször végig néztem a nagyszerü kincseket, most csak azt jegyzem meg, hogy alig létezhetik hely a világon, hol az emberi tudás foka és mérve hatalmasabban nyilatkoznék, mint itt. Valóban minden tudáság, minden tudomány alapja összefoly ez épületben, $\mathrm{s}$ szemlélés közben vallásra, bölcsészetre, müvelődéstörténetre, nyelvtudományra, festészetre, szobrászatra, költészetre, zenére, szóval mindenre kell gondolni - hisz elöttünk van minden, amiből minden fejlődött. Itt éveket tölthetnék, nem napokat, hisz minden parányi tárgy érdekes és az egész harmóniából beszél, a természet harmóniája és utánozhatatlan rendszere, mely az emberiség felvilágosulását mozdította elö, minél mélyebben pillantott az bele. 1/21 órakor kocsin, Hansom $\mathrm{Cab}^{27}$-en jöttem haza, dèjeuner ${ }^{28}$ után pedig naplómat írtam és leveleket. 5 órai theánk után kocsira ültünk, s a nagy utczákon, Nelson emlék, Cleopatra tüje ${ }^{29}$, Westminster Abbey, parlament ház, Themse hídján, Hyde parkban ebédig kocsikáztunk, azután ismét írásokat végeztem, este pedig beszélgetés közt üldögéltünk. Szép, meleg idő.

\footnotetext{
25 értsd tear-free soap - könnymentes szappan

${ }^{26}$ ebédet

${ }^{27}$ egylovas zárt kocsi, ahol a kocsis a kabin mögött/fölött ül (JOSEPH HANSOM alakította ki 1834-ben)

28 ebéd

${ }^{29}$ Cleopatra's Needle - 21 m magas, 180 tonnás gránit obeliszk a Temze partján, Kr. e. 1500 táján készült
} 


\section{Augusztus 15-én}

LORÁND írt, s tudósított, hogy BENCZE állapota változatlan és hogy SZALAY MARISKA hosszú szenvedésének a halál véget vetett. Megint csak szomorú hír!

A délelőttöt ismét Kensington Múzeumban töltöttem, s ebédkor jöttem haza előbb még az Albert emléket ${ }^{30}$ szemléltem meg. Ebéd után vasútra ültünk, s a Kew Gardensnál szálltunk le, a világ leghíresebb botanikai kertjében. Valóban elragadó szép hely ez, s amint a Kensington Múzeum hallgatag gyüjteménye az élölényeknek, az teljesség tekintetében a kert növényvilágával. Majdhogy több 400 ackernél $^{31}$, s együtt díszlik itt az 5 világrész minden nevezetesebb növénye, a lybanoni cédrus, a Victoria regia ${ }^{32}$, s az óriási pálmaházakban a tropikus égöv pálmái, iszalagjai, páfrányai. Egyetlen pázsitja, gyönyörü tülevelü fái, hatalmas cédrusai, tavai, virágágyai, konyhakertjei, erdős részei leírhatatlanok. A pázsiton mindenütt szabadon járhatni, az angol klíma előnye az, hogy nem szárad ki ezért belőle a gyep, hanem üde marad. A tavakat feketenyakú, fehér, fekete hattyúk, vadludak, pelikánok, vadréczék népesítik be, a parton pedig az üdülők ezrei. A legfőbb szépsége pedig a kertnek az, hogy a természet megvan benne, csak rendszerezve, gondozva van, s nincs eredetiségéböl kivetkőzve. A sok üveg és pálmaház mellett van benne pagoda, gloriette, theázó hely stb., s mellette folyik a Themse is, hol élénk hajókázás uralkodik. Esti 6 óráig időztünk itt, s azután a typikus repkényes, virágos angol házak közt ismét a vasúti állomásra mentünk, $\mathrm{s}$ haza indultunk. Óriási a forgalom a vasutakon, majd minden 10 perczben jön, megy egy vonat. Fütty nélkül robog be, az utasok beszállnak, s fütty, csengetés nélkül megint odább megy. Nincs itt izgatottság, lárma, oly megszokott valami ez, mint egy kocsi vagy bricska. A jegyeket mindjárt beszállásnál a pályaudvaron lebélyegzik, a kiszállás előtt elszedik, s conductort $^{33}$ alig látni. 7 órakor ebéd, azután írtam, s 10-kor lefeküdtünk. Szép idő.

\section{$\underline{\text { Augusztus 16-án }}$}

Vasárnap volt, ami pedig Angolországban annyit jelent, hogy e napon semmit sem lehet kezdeni, csak templomba menni, s délután a Hyde parkban sétáló sok embert megnézni. A vasárnapi munkaszünet annyira megy, hogy az istentiszteletek elmúltáig csakis a legfőbb postahivatalokon van szolgálat, minden más forgalom, dolog, munka pihen, sőt még a kerületi vonatok sem járnak. Reggeli után hát mi is templomba mentünk, még pedig a Szt Paulsba a római Péter templom édes testvérjébe. Szúnyognak érzi magát az ember a hatalmas kupola alatt, s majdcsaknem arra gondol, hogy az ég kövesült meg feje fölött kupola alakban. Itt egy hosszúra nyújtott, ceremóniás angol istentiszteletet hallgattunk végig, mely alatt a sok felállásból, majd meg letérdepelésböl bőven kijutott. Az a szép ének, mely talán egyedül itt hallható csak, most szinte vacation járt a sok college boy-al ${ }^{34}$, szintúgy a híres orgonajáték, csak a beharangozás eredetiségét - valóságos harangjátékot - élveztük igazában az épület remeksége mellett. Ezután kocsin a vasúti állomásra mentünk, útközben több utczaszögleten összesereglett népet tartott szóval valami modern apostol. Vasúton nem lehetett rögtön indulni, várni meg nem akartunk, tehát kocsiban maradva érkeztünk Denmark Hillre. Itt először BENNECKE-néhez mentünk, WEBERék nagyanyjához. Három nagynénjük és egy nagybátyjuk is itt lakik. Kedves angol ház, kerttel, üvegtornáczczal. Az öregasszony 84 éves már, s alig lát, de lelkileg friss. Mindnyájan beszéltek németül, ami kellemesen esett. (Magyar

\footnotetext{
${ }^{30}$ Albert emlékmű - VIKTÓRIA királynő férje, ALBERT herceg emlékmüve

${ }^{31} 1$ acre $=4046,86 \mathrm{~m}^{2}-$ a kert nagysága tehát kb. 162 hektár volt (ma 132 ha)

${ }^{32}$ ma Victoria amazonica - amazonasi óriás-tündérrózsa

${ }^{33}$ kalauz

${ }^{34}$ föiskolás fiú
} 
esett volna csak jól!) Igen érdekes hely ez, s az öregasszony is érdekes személyiség. Jól ismerte a híres zeneköltő MENDELSOHN-BARTHOLDYt, sőt vele igen közeli rokonságban állott, ugyanis nővérének leánya volt MENDELSOHN felesége, másrészt pedig fia MENDELSOHN leányát vette nöül. A drawing roomban ${ }^{35}$ hol beszélgetve üldögéltünk componálta a híres „Frühlingsliedjét”, még pedig következő képpen. BENNECKEék kirándultak Windsorba, s MENDELSOHNnak is velük kellett volna jönni, de mikor már indulni akartak, hirtelen meggondolta, s otthon maradásra határozta el magát. Az öreg BENNECKENÉ azonban biztatta, mondván, hogy csak a gyermekek maradnak otthon, s így nem készült más ebéd mint rizspudding, de MENDELSOHN nem volt megtántorítható, eszméi voltak, s nem ment, hanem a drawing roomba ${ }^{35}$ vonult vissza, s a künn beszélgető, csengő gyermeklárma adta neki a hangulatot és benyomást, melynek gyümölcse említett szép dala lőn. Mire a kirándulók visszatértek, a dalt készen leírva mutatta be nekik. (WEBERék szobájában álló zongorát is nagyanyjuk számára 40 év előtt MENDELSOHN kereste ki, s nevét saját kezűleg beírta a baloldalra belül, s nem egyszer játszott e hangszeren, melyen most én a „Kukačka” cseh dal egyszerü dallamát kalimpálgattam!). Ebéden egy angol pap is velünk volt. Az egész létezés itt meglehetős unalmas volt, másként és feszes, kedélyesség nélkül, szintúgy egy másik nagynénjüknél, Aunt ${ }^{36}$ ADÁnál, sőt itt talán még feszesebb. A mi ADÁnk, meg ez az angol ADA bizony áll olyan messze egymástól, mint Magyarország Angliától! Unalmas, lélegzetvisszaszorított délután volt egészben denmark hilli látogatásunk, s mindnyájan könnyebbülve, megfrissülve ültünk vasútra, s robogtunk vissza Londonba, hol kedélyes asztal várt. Szép időjárás, meleg.

\section{Augusztus 17-én}

Délelőtt bevásárlásokat végeztünk az Oxford streeten, s meglátogattuk a világhírü Marshall \& Snelgrove házat, mely minden áruczikket egyesít éppúgy, mint Whiteley, s három utczát fog el. Délfelé a British Múzeumba mentünk, s HELEN, ki velünk volt, hamar átvezetett az egész óriási gyüjteményen, a nevezetesebb dolgokra figyelmeztetve. A legrövidebb általános katalógus is 330 act. lapból áll, s így nem sorolhatom még csak rövid tartalom jegyzékét sem az egész világból, az emberiség első fejlödésétől jelen korig összegyüjtött kincseknek. Csak megemlítem itt, hogy láttam több terem eredeti híres római, egyiptomi, etruszk, görög, assyr műemlékeket, szobrokat, munkákat, hyeroglifes táblákat, láttam a világ összes nyomtatványait representaló könyvtár olvasó termét és főbb részeit, s itt a kézirat gyüjteményben Schiller, Göthe, Baco, Milton, Oliver Cromwell, Carlyle leveleit, Dickens utolsó levelét, Mendelshon, Melanchton, Luther, KeAn, Byron, Burns, TORQUATO TASSO, NEWTON stb kézírásait, munkáinak eredeti fogalmazványaiból szemelvényeket, sokáig időztem az üveg szekrényben kiállított mostanában felfödözött papyrus előtt, mely ARISTOTELES müve, Athén alkotmányáról. Az egyptomi jeképes írás alakjai közt kiválóan érdekeltek a madarak, legtöbbször sas, bagoly, keselyü haris forma madár, ibis fordul elő rajtuk, s a rajzok, vésetek kitűnő formaérzékről tesznek tanúságot, sőt a körvonalak és az állás oly jól ellesett, hogy alig lehet mai napon jobban megcsinálni. A könyvtár évi gyarapodása kb. 30.000 mü, tehát maga ez is egy óriási könyvtár!

Lunchre $^{37}$ egy közeli vendéglőbe mentünk, azután HELEN hazatért, mi meg Madame TUSSAUD óriási, híres viaszfigurák kiállítását néztük meg. Legjobban érdekeltek a NAPÓLEON szobák, hol a sok viaszalak mellett igazán sok eredeti emlék is együtt volt NAPÓLEON korából

\footnotetext{
${ }^{35}$ szalon

36 nagynéni

37 ebédre
} 
és életéböl, s ezek közt legnevezetesebb az a pamlag, melyet Szt. Ilona szigetén használt, s az a madracz és vánkos, melyen meghalt. Földalatti termekben a gonosztevők egész serege látható viaszból, különféle büntettek, kivégzések, melyeket azonban nem igen néztünk, hanem inkább a fölső termekben mozogtunk. Temérdek ember sürgölődött itt, női zenekar játszott, s étkező helyiség is kínálkozik a látogatók kényelmére.

Innét az Oxford és Regent streetre kocsiztunk, s az East Indiai Houseban HeLENnek és MAYnek emlékül vettünk egy karpereczet és melléket. Hazaérkezvén 5 órai theához ültünk, melyre Mrs RICHMOND és Mrs HoulLER jöttek el. Utóbbi neves ifjúsági írónő, s müvei több kiadást értek, atyja híres zenész volt. Vele sokat beszélgettem - jól tudott németül s igazán érdekelte Norvégia, úgy Magyarország is. Thea után olvastam „Gespräche mit Goethe” ECKERMANNtól, melyet HELEN kölcsönzött. Később pedig gyönyörü gemmakat ${ }^{38}$ mutatott HELEN, egy rendszeres több százból álló gyűjteményt, melyek nagy könyv alakú kötetekben (6 köt. mindegyikre két lapra ragasztva) vannak elhelyezve, s a nevezetes antik és modern szobrok miniatur lenyomatait mutatják. Este írtam, majd ismét olvastam említett érdekes müvet. Szép idő, kissé boruló, délután eső is.

\section{$\underline{\text { Augusztus 18-án }}$}

Délelőtt pár bevásárlás után a National Galleryba mentünk. A nevezetes kincsek következöleg vannak 22 teremben elhelyezve: Északi Vestibuleben ${ }^{39}$ olasz freskók, octagonalisban ${ }^{40}$ miscellaniák $^{41}$, keleti vestibuleben ${ }^{39}$ ó-angol iskola mi függ a nyugati vestibuleben ${ }^{39}$ is. I. terem. Tuscan iskola (15-16 száz.), II. franési iskola, III. Tuscan iskola, szintúgy a IV. teremben is. V. Ferrari és bolognai iskola; VI. umbriai iskola, VII. velenczei és brabiai iskola. VIII. paduai és velenczei iskola. IX. Parmai és lombardi iskola. X. flamandriai és német, XI. XII. szintén, XIII. későbbi olasz iskola. XIV. franczia, XV. spanyol; XVI. XVII. régi angol, XVIII és XIX angol; XX és XXI modern angol, XXII Turner gyüjtemény. Röviden fogom megjegyezni azokat a festményeket, melyek reám hatást gyakoroltak, s melyeket hosszabb ideig szemléltem (a catalogus egyik 213, a másik 529 oldal, így bővebben nem ismertethetem a képtárt). A régebbi képek közül: CORREGGIO „Ecce homoja és Szent családja”, Michelangelo 3 képe, Barborelli, Luini, Giovanni képei; Murillo szent családja, egy mongol fiuja, s még két képe, PERUGINo képei, REMBRANDT 14 képe, köztük a pásztorok imádása, GUIDO RENI 7 képe ezek közt: Magdolna, St Jeromos, Lot és leányai elhagyják Sodomát, a szüz megkoronázása, „Ecce Homo”; RUBENS 15 kép; RAFAEL SANZIO gyönyörü képei, s mind sokáig néztem, hisz a legjobbakból tanul igazán az ember, itt van tőle: II. Gyula pápa, alexandriai St. Katalin, a szolga látománya, Madonna di san fisto, a Madonna szt. Jánossal és a csecsemő Krisztussal, a szüzet és a gyermeket st. János és bori st. Miklós tisztelik (Madonna deghi Ansidei), ez a gyönyörü kép felejthetetlen benyomással van a szemlélöre, majdnem olyannal mint a sixtusi Madonna; a képtár 70.000 fontért vásárolta a festményt. Teniers fict. képei, Giovanni Battista TiePolo, Tintoretto Vecello, Titian (VeCEllio) $^{42} 8$ képe, VelazQueZ, Venusti, Veronese (Coliaris), LeONARdo DA Vinci (a szüz a sziklákon), WOUWERMAN, ZAMPIERI. Az angol és modern iskolák képei közül tovább néztem következők festményeit: THOMAS BARKER, COPLEY GAINSBOROUGH, KOGARTH (13 képét), LANDSEER (Sir EDWIN) gyönyörü állatképeit (14 kép), MACLISE, REYNOLDS, ROSETTI, ScotT, Walker, Horace Vernet (I Napoleon), Webster, Wilson, s végre Turner

\footnotetext{
38 ékköveket

39 előcsarnokban

${ }^{40}$ nyolcszögletü teremben

${ }^{41}$ különfélék

${ }^{42}$ helyesen TIZIANO VECELLIO
} 
nagyszámú, sajátságos felfogással készült müveit és két termet betöltő nagyrészt nem kész aquarelljeit. Modorában egész eredeti festő ez; a ködöt, homályt vagy nagy fényhatásban nyilvánuló elmosódottságot, kinemvehetőséget utánozhatatlanul festi; így például kikötőt fest, vagy csatornát, tengert úgy, hogy a szemlélő a napba tekint, s érzi a többi tárgynak erős fény hatásával járó bágyadt képét. Egyéb festményei is közelből teljes elmosódott fátyolos festéköntések, de bizonyos távolból gyönyörü, éles, igazán természet elleste kép kerül ki a látszólag rend és terv nélkül való mázolásokból. Különösen aquarell képei tetszettek nekem, bámulatos színérzéke és genialitása ezekben nyilvánul legjobban.

Délután Harrow on the Hillre mentünk. A vasúti állomás előtt láttuk a nagy criquet versenytereket, melyek a mi versenytereinkhez hasonlítanak. Temérdek ember forgolódott itt, éppen „match” lévén. Félórai vasutazás alatt háromszor „under ground”, azaz a házak alatt menve, megérkeztünk Harrowba, egy igazán kedves angol városkába. A vidék, házak, minden tiszta angol jellegü, s így nagyon érdekelt. EDWARDék házába érve csak nejét találtuk hon, meg a kedves gyermekeket, kikkel nagy barátságot kötöttem, bár alig tudtunk beszélgetni egymással. A kis fiú igazi naivitással azt kérdezte „,hogy hát, ha magyarul tudok beszélni, a cselédek hogyan értenek meg?" EDWARDék igen szépen és kényelmesen laknak, s a ház szinte virágok közé van építve. Ezután HELENnel és a két nagyobbik gyerekkel felmentünk a templomhoz, mely a dombon fekszik, s körülötte temető van. Az eleje ennek terraceszerü, s messze kilátás esik az alattunk elterülö vidékre egész Windsorig, mely egy óriási gyönyörü parkhoz hasonló kép a nemességben, mindenütt avval a bizonyos kékes ködszerü fátyollal. Mindjárt a temető bejáratától jobbra a második sír egy nagy kőlap, s nevezetes arról, hogy Lord BYRON ezen szokott feküdni itteni tartózkodásakor, s a vidéket szemlélve itt írta „Child Harold" gyönyörü költeményét.

A templomot megszemlélve, mely szintén érdekes; igazán angol templom csúcsos nyak nélkül való toronnyal, s falai csupa töréssel kifelé fordított tűzkő darabokkal, ami igen eredeti formát ad neki. A kedves, szép faragott fából készült ajtón át kiérünk a temető végén a városkába, mely úgyszólván csak iskola és ennek függelékét képező épületekből áll. Több száz éves nevezetes „College” ez és igen érdekes. Egy tanterem még most is a régi padokkal van bútorozva és a fal deszkázva fél magasságig, melyen név mellett áll bevésve, köztük sok nevezetes férfiú neve, többek közt két helyen: BYRON 1805. E tanterem után a gazdag könyvtárt tekintettük meg, mely egy híres építész emelte épületben van elhelyezve, sok más emléktárgyakkal együtt és az itt kiképzett később nevezetes szerepet játszó férfiak szobraival vagy festményeivel. Itt van megőrizve Lord BYRON kardja is, melyet Görögországban viselt; egyenes rézmarkolatú kard ez ... baklóval; tokjának végéböl pedig egy 3ad rész hiányzik. Különös érzelmek közt tapintám meg a markolatot, hol e nagy szellem annyiszor pihentette kezét, s hol e kéz oly lángoló érzelmek közt szorítá azt.

A könyvtárból a kápolnába, majd a speech-roomba ${ }^{43}$ mentünk, azután a szép kilátásban gyönyörködvén még egyszer visszamentünk EDWARDékhez. Az itt tanuló diákok most szabadságon vannak, alig egy kettőt láttunk csak feltünő öltözetükben, mely áll cylinderből, kihajtott széles fehér inggallérból, s dolmányszabású fekete kabátból, szürke nadrágból. A fiuk itt olyformán nevelődnek, hogy vagy ötven egy-egy tanárnak vezetése alatt lakik, s külön kis intézetet alkot, s e részekből kerül ki az egész; volt a múlt évben 600 tanuló, a nevelés azonban itt meglehetős költséges, s csak vagyonos embereknek való.

EDWARDéknál ebédelvén igen fényesen, nagyszabásban, de nem ízletesen fözött ételeket köztük a Lagopus scoticus ${ }^{44}$ (grouse) és parfummirozott ${ }^{45}$ pezsgőt, este szép holdvilágnál sétáltunk az állomásra, mely fél óra múlva Londonba vitt. Szép idő.

\footnotetext{
${ }^{43}$ előadóterem

${ }^{44}$ ma Lagopus lagopus scotica - sarki hófajd skóciai alfaja (skót hófajd)

${ }^{45}$ illatosított
} 


\section{Augusztus 19-én}

Sok megnézni való várt ma ránk, így hát reggeli után azonnal indultunk a „Citybe”. Óriási forgalom van itt, főleg a „Bank of London” táján, hol a mindenfelől benyíló utczákból beláthatatlan sorokban egy téren ömlik össze a számlálhatatlan sok omnibus, s minden fajta egy és két lovas kocsi. Perczekig kell egy-egy kocsinak várni, míg hely jut számára, s egy pár lépést haladhat, s valódi kocsi csődület van itt úgy, hogy a gyalog járók egészen eltűnnek, $s$ kocsit- és megint kocsit látni százával szorongva egymás mellett, mintha néptolongás volna jármüvekből. A „Policeman” ${ }^{46}$ higgadt nyugalmát azonban nem zavarja meg ez a szédítő forgalom és élet. Ábrázatjának egy vonása sem rándul meg, szemei biztosan tekintik át a helyzetet, s hang nélkül csak kezével integetve osztja a rendre vonatkozó parancsait, mint a viharban a hajóskapitány, a nép, a kocsisok engedelmeskednek, s minden jól megy.

Legelőször is a „Royal mint”-be, vagyis az állami pénzveröbe mentünk, hová EDWARD, ki a bejárónál várt reánk, engedélyt szerzett a belépésre. Minthogy azonban egyszerre csak négy személynek szabadott belépni, HeLÉN kint maradt. Minket egy vezető kalauzolt végig, s láttuk a nyers fémek olvasztását, a fémlemezek készítését, majd a gépezetet, mely a lemezek kellő vastagságát egyöntetűvé teszi, és azokat egyenesíti. Egyik teremben ezután azok a gépek állanak, melyekbe e lemezek betétetnek, s a kellő nagyságú pénzalakok kiverdesve potyognak az alájuk állított edényekbe, e nyers pénz azután megint egy külön helyiségben tisztíttatik bizonyos folyadékban, majd ismét egy más helyen újra kemencébe kerül, hogy a verésre alkalmas puhaságot kapjon. Igen érdekes ezután a terem, hol a pénz nyomása történik, vagyis ahol a reá kerülő felírást stb. verik reá. Egymás mellett állanak a nagy gépek, s egy csövön felül oszlopszám rakják bele a sima pénzdarabot, mely alul egy csövön készen verve akár a présből a must, potyog, folyik ki különböző edényekbe. Folytonos csilingelés, csengetyüzés hallatszik itt, s khínai felírásos pénzek, minden alakúak, veretüek úgy, mint a nagy angol birodalom gyarmataiban használatosak - potyorásznak ki. Egy perc alatt $80 \mathrm{db}$ készül. Ez a pénz azonban még mindig nem kész, s az utolsó terembe kerül, hol végtelen sorban gőzzel hajtott finom mérlegek állnak. Ezekbe egy-egy csomó kivert pénzt tesznek, s a mérleg önmagától elvégzi a többit, t. i. megméri az egyes pénzdarabokat, hogy az elöírt súlylyal bírnak-e? A mérleg alatt három szük nyílás van, s a kellő súlyú pénzdarab mindig a középső nyílásba esik, a kevesebb súlyú az első, a nagyobb súlyú a harmadik nyílásba. A helyes és előírt súlyú azután mindjárt vászonzacskókba kerül, s megy rendeltetése helyére, míg a többi az elöírt súlyra igazíttatik ki. Az ajtók mindig el vannak zárva, s mögöttünk is mindig becsukták azokat. Nekünk persze nagy benyomást tett ennyi pénz látása, de a szegény munkások kiknek kezein milliók mennek át és akik a pénzt készítik csak úgy bántak vele a megszokottságánál fogva, mint a fadarabokkal. Milyen anomália és sajátságos helyzet ez! Azok kik a pénzt csinálják szegények, s azon keresik kenyerüket, ami a gazdagoknak fényt, hatalmat ád. S milyen sajátságos az is, hogy az érczhez érték van kötve, mely az ember felfogásában támadott, s melyet mindenki elismer, pedig ez is csak úgy cseng mint a harang, vagy az üveg pohár, sőt tán kevésbé szépen.

Délre járván az idő, lunchöt ${ }^{47}$ vettünk magunkhoz, azután EDWARDtól megválva a „London-India Dock”-ok-ba mentünk. Óriási épületek ezek 5-6 emeletben, s igazán a világ szükségleteinek raktárai és forgalmának, a világkereskedésnek képe. Vezetőnk kalauzolása mellett legelőbb is az elefántcsont raktárakba néztünk el. Az ember elbámul, mikor ezer szám látja maga előtt feküdni a kicsinytől a legnagyobbig, vagy 8 minőség szerint osztályozva az óriási emlős agyarait, melyekre patronokkal festik az illető számokat és jegyeket. $\mathrm{S}$ ha tudja azt is, hogy ez a mennyiség egy szállítmány, s a jövő héten az egész raktár üres, hogy nem

\footnotetext{
${ }^{46}$ rendőr

${ }^{47}$ ebédet
} 
sokára ismét megteljen, s elgondolja, hogy minden betelése e helynek egy pár száz elefánt életébe kerül, hát kézzel foghatja azt a tapasztalatot, hogy bizony ez őskorból maradt állatóriás napjai ilyen irtás mellett, gyenge szaporodásának arányában, meg vannak számlálva, és létének küzdelmét az emberi haszon ellenében sokáig már nem viheti. Az elefántcsont leginkább Indiából kerül ide, s kisebbek ládákban, a nagyobbak külön-külön vitorlavászonba bevarrva. Tömör végükből készülnek a golyók, nagyobb dolgok, vékonyabb részükből a nyelek, s üres tövének legvékonyabbjából a zongorabillentyük. A sok elefántagyar közt volt egy pár halmaz orrszarvú szarv is szintén Indiából.

Innét az első emeletbe mentünk, hol beláthatatlan ládasorokban állott a szegfüszeg, s az egész helyiségnek átadta illatát, két minőséget láttunk belőle. Egy emelettel magasabban füszerdiót, majd az utolsó emeletben fahéjat és chinint láttunk óriási mennyiségben. A fahéj akárcsak nádcsomókban van kötegezve, ezeket még itt kiválogatva újrakötegelik, s a köteg végét lesarabolják. Az erős illat egészen áthatja a levegőt. Egy másik dockba mentünk, mely több emeletü, s csak gyapotnak való, ez Austráliából kerül ide, most nem volt éppen idénye, s így csak egy teremben folyt a munka, hol több minőségüt, s fehér és kávébarna gyapotot láttunk. Ezután egy óriási hosszú, alig belátható végü helyre érünk, miután leszállón jöttünk le az emeletekröl, s itt az olvasztó gummi, sellack ${ }^{48}$, borax ${ }^{49}$, különféle festőanyagok rakományai voltak, szóval drogeriek ${ }^{50}$. Utolsónak következett azután a bor illetőleg a pinczehelyiség kisebb nagyobb alakban, vagy 60.000 hordó telve madeira, portói, sherry stb. borokkal. Markunkba nyomtak egy lécz végére erősített lámpát, s így barangoltunk ide oda az egyik pinczében, mely 400 yard $^{51}$ hosszú, de 7 ilyen pincze van. Egy hordó madeirából azután kóstolót adtak, mely ugyancsak kitünő volt. Nagy fáradtan néztük meg e nap még a dockok megtekintése előtt a híres „Tower” is, egy nagy megerősített régi várszerü, régibb és újabb épületek halmaza. Leírását itt bőven, de még rövidítve sem adhatom - hisz elég helyen megtalálható, csak saját utamat jegyzem föl. A bemeneteket őrző medvebőrös piros kabátos fehér szíjjas gránátosokat és a történelmi öltözékü kapusokat elhagyva először is a „Regaliákat”, vagyis az angol királyi ékszereket, koronákat és jogarokat, királyi jelvényeket láttuk. Főleg VICTORIA királyné koronája, teljesen gyémántból óriási rubin és zaphir kövekkel ékítve, kapta meg figyelmünket, majd a Kohinur ${ }^{52}$ utánzata, innét az udvarok temérdek régi ágyúi közt torony csigalépcsőn a White Towerbe mentünk Sz. János kápolnájába, azután a gyönyörü gazdag és ízlésesen elrendezett fegyvertárba. Egész sorozat pánczélos lovagok ülnek itt lándzsásan, hü utánzatban készült lovaikon és egy egész sereg gyalogos álldogál mindenfelé teljes fegyverzetben. Puskákból, lándzsákból, bajonettekből, pisztolyokból, kardokból, sisakokból díszítések, korlátok vannak készülve, mely fegyverek tömegét a Krími hadjáratban használtak teszik. Ezután egy nagy udvaron haladtunk át, s terebélyes fák alatt egy négyszögü kikövezett téren állottunk meg, melynek közepén kőlapra vésve olvasható, hogy e helyen hullottak le BOLEY[N] ANNA királyné, MARGIT Contess of Salisbury, KataLIN királyné, JANE Viscountess RochFORD, Lady JANE GREY, ROBERT DEVEREuX fejei a hóhér bárdja alatt. Ezután a kivégzési hely mellett levő fogságba mentünk, melynek sok nevezetes foglya volt, azok is, kik az udvaron elvérzettek. Nevük és a kőbe vésett faragványaik, szomorú itt időzésüket mai nap is hirdetik a falon. JANE GREY neve is itt van.

A Towerben még sok más történelmi kivégzés és fogoly volt. Többek közt: ARUNDEL Richard és FÜlÖP, ANNA ARKEN, DAVID BRUCE (scot király), Ld. BuCKINGHAM, GeORG

\footnotetext{
${ }^{48}$ trópusi pajzstetvek (Kerria lacca) elgyantásodott váladékából nyert anyag

${ }^{49}$ a bórsav nátriummal alkotott sója (nátrium-tetraborát), vízben oldódó, lúgos kémhatást eredményező anyag

${ }^{50}$ vegyszerek

${ }^{51} 1$ yard $=0,9144$ méter -400 yard tehát kb. 366 méter

${ }^{52}$ Koh-i-Noor (,a fény hegye”) - 105 karátos fehér briliáns - a brit koronaékszerek része (csiszolás elötti tömege 181 karát volt
} 
Buckingham, Hubert de Burgh, Sir Simon Burley, Georg Duke of Clarence,

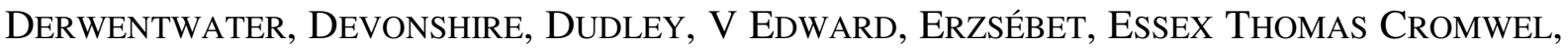
Essex Robert, Fawkes, Ferrers, Fisker, Fitzgerald, Flambard, Griffin, Hamilton, Hestings, Vi Henrik, Katharine Howard, JefFreys, Kenmure, Land, Lisle, Lovat, Monk, Monenouth, Sir Th. More, Mortimer, Niksdale, Norfolk, Northumberland, Overbury, Perrott, Sir Raleigh, Rochford, Russell, Symons, StefFord, Sydney, VANE, VIENNE, WARBECK, WARWICK, WENTVELl, WrEN, WyatT nevekhez füződik legtöbb történelmi emlék e helyen.

Az egész nap szakadó eső bolyongásaink közibe igen kellemetlen volt, de azért sokat láttunk ma, sok érdekeset és emlékezeteset. 5 óra felé tértünk haza, meglehetősen kifáradva és bágyadva.

\section{Augusztus 20-án}

Leveleket és újságot kaptunk hazulról, mik igen megörvendeztettek. Reggel írtam, 11 órakor azután HeLENnel vasútra ültünk, s a „Surreybe "53 mentünk Boxhillbe ${ }^{54}$, Clevlandba BENECKEékhez. Egy órai utazás után, mely megismertetett a Surrey kedves, parkszerü vidékével, megérkeztünk a gyönyörü Boxhillre ${ }^{53}$. A vasúton várt az öreg BENECKE, kivel a tőszomszédban fekvő kastélyába mentünk. Gyönyörü kert közepén fekszik a teljesen angol, minden kényelemmel berendezett ház, s a virágok az egész birtokot ellepik, falakat, szobákat. Látogatóba jött Dr LUCIUS is Németországból, a volt minister, BISMARCK, nagy emberének testvérje. BENECKEék családja a kedves háziasszonyból és két leányából áll, akik azonban már nem fiatalok. Az egyik kissé különcz, de utazott Amerikában, s most Norvégiából tért vissza; a másik igen tehetséges festőnő, s több száz aquarelljét élvezettel néztük, föleg vidékeket igen jól fest, s francziaországi naplójainak fehér-fekete illusztrációi kedvesek. Barátságos, rokonszenves család, s igen kellemesen töltöttük velük az időt. Igen jó lunch ${ }^{55}$ után kikocsikáztunk a szomszéd hegyre, hol az erdőket a tölgy és bükk mellett föleg a vadon tenyésző, több száz éves Taxus és puszpáng ${ }^{56}$ fák teszik. Sürü falakat képez a puszpáng az utak mellett, s mint alj is zöldell, áthat[olhatat]lan bokrokban, de sokszor kétszeres sorvastagságú törzse van és több méter magas lesz; innét e helység neve Boxhill ${ }^{53}$. Az egész vidék egy gondosan tisztán tartott óriási park jellegét viseli magán. Átmentünk egy szomszéd család kastélyához is, s BENECKEék látogatást tettek, mi azonban kocsin maradtunk. Sajnos az eső úgy eleredt, hogy a vidék szépségeit kellőleg nem élvezhettük, s haza kocsizás közben Dorking városkának képét is csak homályosan láttuk. 5 órai theánk után a háziasszony zongorázott, majd egy rajzot mutatott, melyet MENDELSOHN-BARTHOLDY készített, s neki ajánlva adott. Kézírása és névaláírása a kép alatt van. Estefelé hagytuk el ezt a szép helyet és kedves embereket, s a kultúra magas fokán álló Surreyből egy óra múlva ismét Londonba szállított a vonat. Délelőtt szép idő, délután eső. LOUIS megjött Norvégiából.

\section{Augusztus 21-én}

Délelőtt bevásárlásokat végeztünk HeLENnel. Délután DoRÁval a South Kensington Múzeumba mentünk, melynek óriási gazdag és gyönyörü gyüjteményeit sokáig nézegettük. Az ember elámul ennyi kincs és érték látásán, s beleszédül a nézésbe. Nem bírom még csak

\footnotetext{
${ }^{53}$ grófság (megye) Délkelet-Angliában

54 helyesen Box Hill

55 ebéd

${ }^{56}$ Buxus sempervirens - örökzöld puszpáng (angolul Common Box, European Box vagy Boxwood)
} 
legrövidebbre fogva is benyomásaimat ecsetelni, s csak a katalógusra utalhatok. Ma belépti díjjat fizettünk, mert a művészek dolgoztak mindenfelé, rajzoltak, festettek. Innét átmentünk a természetrajzi múzeumba, s a madárgyüjteményt futólagosan átnézvén azonnal SHARPE- ${ }^{57}$ kerestük föl. Igen szívesen fogadott, és örült, hogy felkerestük. Itt találtam HARTERT-et ${ }^{58}$ is, ki 6 hónapra jött Londonba a catalogus szerkesztésében részt veendő, s megismerkedtem GRANT-tal $^{59}$ is, ki éppen most a tyúkokat dolgozva föl, s kért, hogy Magyarországból küldjek neki foglyokat stb. Sokáig beszélgettünk, míg csak be nem zárták 6 órakor a múzeumot. SHARPE a vasútra ment, mert Windsorban nyaral családja, elkísértük hát egy darabig. Szívesen meghítt magához vasárnapra, de nem fogadhattuk el meghívását, mert az állatkertet akartuk e napon végig nézni. HARTERTet is elkísértük jó darabig, ki érdekesen beszélt afrikai útjáról, s említette, hogy a Tot. calidriseket $^{60}$ ő is bokrok közé látta többször szállni. Élvezetes, tanulságos órák után értünk haza. Este olvastam, majd vacsora után LouISsal felvételeim utolsóinak negatívját készítettük el.

\section{$\underline{\text { Augusztus 22-én }}$}

Reggel HELEN elutazott egy barátnéjához több hétre, s így tőle végleg elbúcsúztunk. Ezután kocsiba ültünk és a Westminster Abbeyhoz hajtottunk, ehhez a nevezetes, gyönyörü, régi nagy templomhoz, melyben Anglia királyai, legjelesebb államférfiai, vezérei, költői, írói és tudósai, művészei alusszák örök álmaikat. Áhítattal léptem be ebbe az igazán szent csarnokba, sokáig merengve PitT, Maconly, BuRns, EMERson, Coleridge, WALTER SCOTT, Dickens, STUART MARIA, ERZSÉBET királyné sírjainál. Különösen a 7. [VII] HENRIK kápolnája gyönyörü, itt fekszik CROMWELL is. Láttuk a 600 éves angol trónt, állami kardot is. Meghatva távoztunk el déltájban, egy darab múltat és emlékezetet hozván magunkkal.

Délután a Royal Naval Exhibitionba ${ }^{61}$ mentünk, hol LEWISsel találkoztunk. Az egész angol tengerészet fejlődésétől máig, nagyszerü kiállításban, mi annyival és inkább tanulságos volt, mert hisz az angol tengerészet a világ első tengerészete. Itt sem bírok még csak általános képet is hamarjában vázolni, de legtöbb érdeket a NELSON emlékek, a FRANKLIN expeditio, az óriási ágyuk (22 lépés hosszú!), a teljes nagyságú Victory modell, NELSON trafalgari hajója, a Maxim puska, a torpedók, a villamos jelzőlámpák, az angol tengerészek katonai gyakorlata, az Eddystorm féle nagy világító torony, melyre liften felszálltunk, egy imitált jéghegy, a búvárok működése víz alatt, a trafalgari ütközet panorámája, a hajómodellek, az összes angol hadihajók utánzata, az egész világ tengereinek különböző kicsiny kiadásban szemlélhető áramlatai, a tengerészetre vonatkozó képkiállítás kötötték le. Volt léggömb felszállás is, melyben két férfi és egy miss vettek részt. Este gyönyörü mutatvány a villamos jelzőkkel, majd a világítótorony villamos csóvái és pompás tüzijáték. 10 óra után értünk vissza, szinte ki voltam merülve a sok látottaktól.

\footnotetext{
57 RiCHARD BOWDLER SHARPE (1847-1909) - angol ornitológus, a British Múzeum madárgyüjteményének kurátora

58 ERNST JOHANN OTTO HARTERT (1859-1933) - német ornitológus, LIONEL WALTER RoTSCHILD tringi magánmúzeumának madártani kurátora. Fő müve a Die Vögel der paläarktischen Fauna (1903-1922)

${ }^{59}$ WILLIAM ROBERT OGILVIE-GRANT (1863-1924) - skót ornitológus, 1909-1918 között (SHARPE után) a British Múzeum madárgyüjteményének kurátora

${ }^{60}$ ma Tringa totanus - piroslábú cankó

${ }^{61}$ Királyi Tengerészeti Múzeum (Kiállítás)
} 


\section{Augusztus 23-án}

Vasárnap lévén ismét nem sokat lehetett kezdeni - ez nap mindenki és minden pihen. Délelőtt a Magyarországból kapott nagy csomó újságot böngésztem át, s szinte elfelejtettem, hogy Angliában vagyok - teljesen elfogták bensőmet az otthon dolgai, s egy kis honvágyat is támasztottak bennem. Délután az állatkertbe kocsiztunk, s a világ első Zoological Gardenjét nagy élvezet és tanulság közt néztük végig. Vasárnap e kert nincs nyitva a nagy közönség számára, s csak a Zoological Society ${ }^{62}$ egy tagjának szívessége folytán léphettünk be, kitől HELEN jegyeket szerzett. E napon tehát csak a tagok ismerősei nézhetik meg a kertet, s így nincs sok ember itt, ami kellemes, s nem volt legalább oly tolongás, mint a Naval Exhibitionban, hol majd agyonnyomták egymást az emberek. HARTERTet nejével szintén itt találtam, s pár szót válték vele; csak nemrégiben nősült. Kellemes órák után tértünk haza, elég fáradtan a sok látottak benyomásával, melyek felsorolását nem adhatom, s a katalógusra utalok. Elég legyen itt, hogy a Zoological Society ${ }^{61}$ vezetése alatt áll e kert, mely egylet titkára SCLATER ${ }^{63}$, s berendezése, nagyszerüsége mintaszerü.

\section{Augusztus 24-én}

Reggeli után DoRÁval a Kensington Múzeum természetrajzi épületébe mentünk SHARPEhoz. Igen szívesen fogadott, szintúgy HARTERT és GRANT. SHARPE megmutogatta ezután a 300.000 db bőrt számoló gyüjtemény nevezetesebb dolgait, köztük HuME ${ }^{64}$ és GODMAN ${ }^{65}$ nagyszerü gyüjteményeit. A bőrök fiókokban vannak elhelyezve, melyeken az egyes fajok neve áll, a fiókokban azután üvegfedelü skatulyákban vannak a kisebb börök. Bámulatos gazdag gyüjtemény ez, föleg SHARPE müve. Hogy fogalmat adjak a sorozatokról, hát megemlítem hogy a Sturnus vulgarisból 300 bör van, s a legritkább fajokból is sorozatok. Lusciniola melanopogon $^{66}$ van 34 bör, legtöbb Indiából téli tollazatban, mely feltűnő világos és fakultas, s a fekete részek rozsda veresbe játszók. Van e fajból sok Egyptomi példány is, ezek inkább hasonlók a magyar példányokhoz. Megnéztük a sok Hierofalco islandicust ${ }^{67}$ és a Holboelit. ${ }^{68}$ A seregélygyüjtés arra az eredményre hozta SHARPEt, hogy Európában tulajdonképpen 3 féle van a vulgaris (LINNÉ madara), a purpurascens bíbor fejjel és nyakkal és a kettő közt álló: bíbor nyak és fejjel de zöldzománc fültájjal. Ez utóbbi főleg az Angliában honos példányok jellege. Megmutatta ezután SHARPE a Strix flammeákat ${ }^{69}$, melyek itt világos fehéres hasúak, majd a kékbegyeket, kolibriket, Cyniriseket ${ }^{70}$ stb. Acr. aquaticus ${ }^{71}$ csak $5 \mathrm{db}$ van, L. melanopogon $^{65}$ tojás pedig úgyszintén, fészek nincsen. A tojásgyüjteményben a tojások pamuton egymás mellett vannak elhelyezve üveg fedelü szekrénykékben, fiókokban illetőleg.

\footnotetext{
${ }^{62}$ Zoological Society of London (ZSL) - 1826-ban alapították, két állatkertet müködtet, a London Zoo-t és a Whipsnade Zoo-t. Ma nemzetközi tudományos, természetvédelmi és oktatási szervezet.

${ }^{63}$ PHILIP LUTLEY SCLATER (1829-1913) - angol ügyvéd, zoológus (ornitológus), ő határozta meg a világ főbb zoogeográfiai régióit. 1860-1902 között, 42 évig a Zoological Society of London fótitkára volt.

${ }^{64}$ ALLAN OCTAVIAN HUME (1829-1912) - köztisztviselő, ornitológus, kertész, politikai reformer Brit-Indiában. Az indiai madártan atyjának, mások pápájának is nevezik. Több mint 80.000 példányos gyüjteményét a British Múzeumnak adományozta.

${ }^{65}$ FREDERICK DUCANE GODMAN (1834-1919) - angol entomológus, ornitológus, a British Ornithologists' Union alapító tagja, OSBERT SALVINnal együtt a közép-amerikai fauna és flóra szakértője, gyűjtője, gyüjteményüket - benne mintegy 520.000 madárbőrt - a British Múzeumnak ajándékozták.

${ }^{66}$ ma Acrocephalus melanopogon - fülemülesitke

${ }^{67}$ ma Falco rusticolus - északi sólyom

${ }^{68}$ ma Falco rusticolus - északi sólyom

${ }^{69}$ ma Tyto alba - gyöngybagoly

${ }^{70}$ ma Cinnyris - a nektármadárfélék (Nectariidae) egyik neme

${ }^{71}$ ma Acrocephalus paludicola - csíkosfejü nádiposzáta
} 
Megismerkedtem SHARPE egyik leányával is ki a tojásgyüjteményt rendezte és czédulázta, s láttam dolgozva SMITH ${ }^{72}$ madárfestőt és több új nagy KeULEMANS ${ }^{73}$ féle képet. SHARPEval még sokáig beszélgettünk azután, s ö elmondta, mily nehezen küzdte fel magát, s kevés pénzből lassan gyüjtött, de már 20 éves korában megírta nagy monográfiáját a jégmadarakról. Búcsúzáskor mindnyájukat, SHARPEt, HARTERTet, GRANTot meghívtam otthonomba, viszont SHARPE minket, sajnálkozását fejezve ki, hogy ittlétünk alatt nem tehetett többet érdekemben. Öszinte meleg kézszorítással váltam meg a világ egyik legelső ornithologjától, ki oly élénk barátságos jóindulattal volt irántunk, úgy szintén HARTERTtől és GRANTtól is. Még egy üdvözletet adtak velem Magyarország számára, hol oly kellemesen érezték magukat a congressus $^{74}$ alatt, azután megváltam tőlük. Ebéd után felvételeimből copíroztam néhányat, majd írtam és olvastam EWALD FLÜGEL müvét: „Carlyle’s Religiöse und sittliche Entwicklung und Weltanschauung" nagy élvezet közt. Theára Miss FLORENCZ egykori angolmesternőm látogatott meg bennünket, ki Pozsonyból minden második évben elrándul szülőföldjére. Később EDWARD jött, s vacsorán is itt maradt.

\section{$\underline{\text { Augusztus 25-én }}$}

Szemem gyulladásba ment és így nem mentem ki a szobából, hanem míg DORA MAY-el bevásárolni ment, fényképfelvételeimből copíroztam, majd GöTHE [GOETHE] beszélgetéseit olvastam ECKERMANNtól, bár csak egy szemmel. Délután kikocsiztunk az Oxford streetre és a Hyde parkba, azután FLÜGEL müvét Carlyleről olvastam és BENCZÉnek írtam. HARTERT fényképét küldte, minek igen örültem, pár sor kíséretében. Szemem nagyon kellemetlenkedett, s megnehezíté munkámat írás és olvasás közben. Este LEWIS fényképeit nézegettük. Igen őszies borult, hűvös időjárás nagy széllel és egy kevés esővel is.

\section{Augusztus 26-án}

Elutazásunkat holnapra határoztuk, így hát helyén van, hogy vázlatos képét itt adjam a British Múzeum kiállított madárgyüjteményének. A fökapun belépve nagy elöcsarnokba érünk, melyből a lépcsők felvezetnek. Ez előcsarnok közepén egy óriási bálna csontváz áll, körülötte pedig 7 üvegszekrényben I. Csupa Machetes pugnax ${ }^{75}$ illustrálja biológiai csoportokban az egy fajnak egyed szerint való külön tollazat színét, testnagyságát, mely még évszak szerint is változik. II. szekrény téli havas képe varjakkal, tengeliczekkel. III. a mimikrimus illustrálása Syrrhaptesekkel $^{76}$, pusztai rágcsálókkal, gyíkokkal, Saxicolákkal, Cursoriussal ${ }^{77}$ stb. IV. Albinizmus az egész állatvilágból. V. Melanizmus az egész állatvilágból. VI. a domesticatio változtatása. VII. mimicrizmus a havon.

A csarnok oldal fülkéit az embertől kezdve végig a növényeken át fejlődés és összehasonlító szervezet, boncztan világosítja meg. Ott van a madárcsaládok csontváza, belső szervezete, tollképződése, láb, szárny stb. preparatuma minden jellegzetes sorozatban. Végre a fö madár typusok képviselöi: az albatros a repülés, a strucz a futás és az óriás pinguin az uszás netovábbja és megtestesítése. A földszinten mindjárt a bejárónál balra vannak a madarak systhematikus sorrendbe számos fészekkel, középen pedig egyes madárfajok

\footnotetext{
72 JOSEPH SCHMIT (1836-1929) - holland származású angol madárillusztrátor

73 JOHN GERRARD KEULEMANS (1842-1912) - holland származású, de élete nagy részében Angliában dolgozó madárfestő, ő illusztrálta a 19. század végén megjelent madártani művek legnagyobb részét

${ }^{74}$ II. Nemzetközi Madártani Congressus, Budapest, 1891

${ }^{75}$ ma Philomachus pugnax - Pajzsoscankó

${ }^{76}$ Syrrhaptes paradoxus - talpastyúk

${ }^{77}$ Cursorius cursor - futómadár
} 
biológiai csoportjai oly híven készítve, hogy az utánzat sem lehet jobb. A növényzet, a talaj minden teljesen olyan, mint a mily helyen az illető madár költ. Négyszögletü üveg bura alatt asztalkákon állanak e csoportok s következők (fészekkel, tojásokkal vagy fiatalokkal):

\section{Mormon arcticus ${ }^{78}$}

2. Oidemia nigra ${ }^{79}$

3. Somateria mollissima

4. Aqu. crisaetus $^{80}$

5. Aqu. albicilla ${ }^{81}$

6. Cerchneis tinnunculus ${ }^{82}$

7. Acc. nisus $^{83}$

8. Thal. pelagica ${ }^{84}$

9. Ardea cinerea

10. Phalaropus hyperboreus ${ }^{85}$ tojásokkal

11. Scolopax rusticola

12. Larus argentatus

13. Larus canus

14. Larus ridibundus

15. Larus fuscus

16. Sterna minuta ${ }^{86}$ fluviatilis $^{87}$ és arctica $^{88}$ gyönyörü nagy csoportok egész kis fészektelep fiatalok és tojásokkal

17. Cursorius gallicus ${ }^{89}$

18. Lagopus alpinus ${ }^{90}$

19. Tetrao tetrix

20. Tetrao urogallus

21. Oedicnemus crepitans ${ }^{91}$

22. Aeg hiaticula ${ }^{92}$

23. Tringa alpina ${ }^{93}$

24. Tringa ca[n]nutus ${ }^{94}$

25. Fulica atra

26. Totanus calidris ${ }^{95}$

27. Totanus glottis ${ }^{96}$

\footnotetext{
${ }^{78}$ ma Fratercula arctica - lunda

${ }^{79}$ ma Melanitta nigra - fekete réce

${ }^{80}$ ma Aquila chrysaetos - szirti sas

${ }^{81}$ ma Haliaeetus albicilla - rétisas

${ }^{82}$ ma Falco tinnunculus - vörös vércse

${ }^{83}$ Accipiter nisus - karvaly

${ }_{85}^{84}$ ma Hydrobates pelagicus - viharfecske

${ }^{85}$ ma Phalaropus lobatus - vékonycsőrü víztaposó

${ }^{86}$ ma Sternula albifrons - kis csér

${ }^{87}$ ma Sterna hirundo - küszvágó csér

${ }^{88}$ ma Sterna paradisaea - sarki csér

${ }^{89}$ ma Cursorius cursor - futómadár

${ }^{90}$ ma Lagopus muta - havasi hófajd

${ }^{91}$ ma Burhinus oedicnemus - ugartyúk

${ }_{92}^{9}$ ma Charadrius hiaticula - parti lile

${ }^{93}$ ma Calidris alpina - havasi partfutó

${ }^{94}$ ma Calidris canutus - sarki partfutó

${ }^{95}$ ma Tringa totanus - piroslábú cankó

${ }^{96}$ ma Tringa nebularia - szürke cankó
} 
28. Numenius arquatus ${ }^{97}$

29. Gallinago scolopacina ${ }^{98}$

30. Crex pratensis ${ }^{99}$

31. Gallinula chloropus

32. Oriolus galbula ${ }^{100}$

33. Turdus auritus ${ }^{101}$

34. Columba palumbus

35. Haematopus ostralegus

36. Sarcoramphus gryphus ${ }^{102} 2$ öreg csontváz és pelyhes

37. Haliaetus pelagica ${ }^{103}$

38. Bubo maximus ${ }^{104}$

39. Podiceps minor ${ }^{105}$ és 40. cristatus

41. Colymbus arcticus ${ }^{106}$

42. Circus pygargus és 43. cyaneus

44. Anas strepera

45. Mareca penelope $e^{107}$

46. Spatula clypeata ${ }^{108}$

47. Falco aesalon ${ }^{109}$

48. Querquedula crecca ${ }^{110}$

49. Fuligula cristata ${ }^{111}$

50. Mergus serrator

51. Anas ferina ${ }^{112}$

52. Asio otus

53. Phoenicopterus antiquorum ${ }^{113}$

54. Puffinus anglorum ${ }^{114}$

55-56. Stercorarius parasiticus 2 szekrény

57. Harporhynchus lecontii ${ }^{115}$

58. Charadrius pluvialis ${ }^{116}$

59. Actitis hypoleucos

60. Aegialitis cantianus ${ }^{117}$

${ }_{97}^{97}$ ma Numenius arquata - nagy póling

${ }^{98}$ ma Gallinago gallinago - sárszalonka

${ }^{99}$ ma Crex crex - haris

${ }^{100}$ ma Oriolus oriolus - sárgarigó

101 ma Streptopelia turtur - vadgerle

102 ma Vultur gryphus - andoki kondor

${ }_{103}^{1}$ ma Haliaeetus pelagicus - óriásrétisas

${ }^{104}$ ma Bubo bubo - uhu

${ }^{105}$ ma Tachybaptus ruficollis - kis vöcsök

${ }^{106}$ ma Gavia arctica - sarki búvár

${ }^{107}$ ma Anas penelope - fütyülő réce

108 ma Anas clypeata - kanalas réce

${ }^{109}$ ma Falco columbarius - kis sólyom

${ }^{110}$ ma Anas crecca - csörgő réce

${ }^{111}$ ma Aythya fuligula - kontyos réce

112 ma Aythya ferina - barátréce

113 ma Phoenicopterus roseus - rózsás flamingó

${ }_{114}^{114}$ ma Puffinus puffinus - atlanti vészmadár

115 ma Toxostoma lecontei - sivatagi gezerigó

${ }^{116}$ ma Pluvialis apricaria - aranylile

${ }^{117}$ ma Charadrius alexandrinus - széki lile 
61. Lagopus scoticus ${ }^{118}$

62. Phasianus colchicus

63. Gallus domesticus

64. Argus giganteus ${ }^{119}$

65. Cotile riparia ${ }^{120}$

66. Alcedo ispida ${ }^{121}$

67. Hirundo rustica egy darab háztetővel

69. 2 csoport tropikus madár

71. 2 csoport paradicsommadár.

Külön üvegszekrényben egy teljes Didus ineptus ${ }^{122}$ csontváz és láb, azon kívül e kihalt madár olajfestménye, mely megőrizte alakját. A kép felső részén e felírás van: by G. EDWARDS F. R. \& AD. 1759. Szintén nagy külön szekrényekben vannak több példányban I. kiwi csontváz, fiatal és tojások is. II. strucz. III. Rhea americana. IV. Dromeus novae hollandiae ${ }^{123}$; mindegyikből több példány, fiatalok és tojások, csontváz. Nagyszerü biológiai csoport egy egész falrészt elfogva a Sula bassana ${ }^{124}$ fészkelő telepének utánzata, egy kis képe a Basrocknak, mely Scotia keleti sziklás partján 420 láb magasan emelkedik. Ezer és ezer szám fészkel itt a Sula, s 4 kitünő fotografia mutatja a falon az ott uralgó életet. A biológiai csoport fö része a Sulák fészkelése, van 5 fészek, több tojás, 2 nagyobb egy kis pelyhes és egy fióka a mint a tojásból kibúvik, 5 öreg madár. A sziklák igazi kövek, felső részükön, egy párkányon 9 db Uria lomvia üldögél tojásaik körül, míg jobbra egy Larus tridactilus ${ }^{125}$ a sziklán és egy másik fészkén pihen. Nagyszerüen van ez a kép csinálva s teljesen természethű utolsó vonásában is.

A lépcsőkön felmenve a főlépcső kétfelé ágazásánál ül DARWIN márvány szobra, s lenéz a csarnokra, az első emelet oldalfolyosóit ismét biológiai madárcsoportok ékítik, még pedig a jobb folyosón van 62 kis, asztalon álló üvegszekrényben GouLD ${ }^{126}$ híres kolibri gyüjteménye elhelyezve. A biológiai csoportok azonban túltömöttek s igen symetrikusak, akár egy pillangógyüjtemény. A bal folyosón következő biológiai csoportok vannak:
1. Anthus obscurus ${ }^{127}$
2. Lycos monedula ${ }^{128}$
3. Garrulus glandarius
4. Pica caudata ${ }^{129}$
5. Sturnus vulgaris
6. Saxicola oenanthe $e^{130}$
7. Acrocephalus streperus ${ }^{131} 3$ szekrény

${ }_{118}$ ma Lagopus lagopus scotica - a sarki hófajd skóciai alfaja (skót hófajd)

${ }^{119}$ ma Argusianus argus - Argosz-páva

${ }^{120}$ ma Riparia riparia - partifecske

${ }^{121}$ ma Alcedo atthis - jégmadár

122 ma Raphus cucullatus - dodó

123 ma Dromaius novaehollandiae - emu

${ }^{124}$ ma Morus bassanus - szula

125 ma Rissa tridactyla - csüllő

126 JOHN GOULD (1804-1881) - angol ornitológus és madárfestő, CHARLES DARWIN munkatársa, Ausztrália madarainak és emlőseinek kutatója és monográfusa, a kolibrik elismert szakértője, több madárfaj viseli a nevét

${ }^{127}$ ma Anthus petrosus - parti pityer

${ }^{128}$ ma Corvus monedula - csóka

${ }^{129}$ ma Pica pica - szarka

${ }^{130}$ ma Oenanthe oenanthe - hantmadár

${ }^{131}$ ma Acrocephalus scirpaceus - cserregő nádiposzáta 
8. Acr. phragmitis ${ }^{132}$

9. Ficedula sibilatrix ${ }^{133}$

10. Ficedula trochillus ${ }^{134}$

11. Sylvia hortensis ${ }^{135}$

12. Sylvia cinerea ${ }^{136}$

13. Erythacus luscinia ${ }^{137}$

14. Lanius collurio

15. Pratincola rubetra ${ }^{138}$

16. Pratincola rubicola ${ }^{139}$

17. Caprimulgus europeus

18. Turdus musicus ${ }^{140}$

19. Turdus viscivorus

20. Turdus torquatus

21. Merula vulgaris ${ }^{141}$

22. Erythacus rubecula

23. Cuculus canorus fiat Accentor modularis ${ }^{142}$ fészekben, amint az öregek táplálják

24. Panurus biarmicus

25. Troglodytes parvulus ${ }^{143}$

26. Emberiza schoeniclus

27. Emberiza citrinella

28. Emberiza miliaria ${ }^{144}$

29. Sylvia atricapilla

30-31. Sylvia undata ${ }^{145} 2$ szekrény

32. Regulus cristatus ${ }^{146}$

33. Motacilla Rayi ${ }^{147}$

34. Linota cannabina ${ }^{148}$

35. Linota rufescens ${ }^{149}$

36. Anthus pratensis

37. Pyrrhula europea ${ }^{150}$

38. Muscicapa atricapilla ${ }^{151}$

\footnotetext{
${ }^{132}$ ma Acrocephalus schoenobaenus - foltos nádiposzáta

${ }^{133}$ ma Phylloscopus sibilatrix - sisegő füzike

${ }^{134}$ ma Phylloscopus trochilus - fitiszfüzike

135 dalos poszáta

${ }^{136}$ ma Sylvia communis - mezei poszáta

${ }^{137}$ ma Luscinia luscinia - nagy fülemüle

138 ma Saxicola rubetra - rozsdás csuk

${ }^{139}$ ma Saxicola rubicola - cigánycsuk

${ }^{140}$ ma Turdus philomelos - énekes rigó

${ }^{141}$ ma Turdus merula - fekete rigó

${ }^{142}$ ma Prunella modularis - erdei szürkebegy

${ }^{143}$ ma Troglodytes troglodytes - ökörszem

${ }^{144}$ ma Emberiza calandra - sordély

145 bujkáló poszáta

${ }^{146}$ ma Regulus regulus - sárgafejü királyka

${ }^{147}$ ma Motacilla flava flavissima - sárga billegető angliai alfaja

${ }^{148}$ ma Carduelis cannabina - kenderike

149 ma Carduelis flammea cabaret - barna zsezse

${ }^{150}$ ma Pyrrhula pyrrhula - süvöltő

${ }^{151}$ ma Ficedula hypoleuca - kormos légykapó
} 
39. Muscicapa grisola ${ }^{152}$

40. Fringilla coelebs

41. Parus cristatus

42. Parus palustris

43. Parus major 2 csoport

44. Parus caerulens

45. Parus caudatus ${ }^{153} 2$ csoport

46-47. Cocothraustes vulgaris ${ }^{154} 2$ szekrény

48-49. Anthus arboreus ${ }^{155} 2$ szekrény

50-51. Alauda arvensis 2 szekrény

52. Loxia curvirostra

53. Passer domesticus

54. Fringilla flavirostris ${ }^{156}$

55. Chrysomitris spinus ${ }^{157}$

56. Ligurinus chloris ${ }^{158}$

58. Certhia familiaris 2 csoport (különféle fészkelés)

59. Carduelis elegans ${ }^{159}$

60. Sitta caesia ${ }^{160}$

61. Cinclus aquaticus ${ }^{161}$.

Jobban utánozni a természetet, mint ezekben a csoportokban utánozva van, nem hiszem, hogy lehetne. A tökély legmagasabb fokán állanak mind, és müvésziesek, tanulságosak. Minden biológiai csoport előtt táblácska van, melyen a madár latin és angol neve áll, azonkívül rövid ismertetése, előfordulása. A systematikai gyüjteményben ez egyes fajokról igen sokszor a csontváz és fészek is ott van. Láttam az Alca impennis ${ }^{162} 2$ tojását, egy kitömöttet Labradorból és egy csontvázat.

Az emlősök egy és az osteológiai gyüjtemény a baloldal első és második emeletét foglalják el, míg a paleontológiai rész a földszint jobb felét, az ásványok az első, a növények a második emeletet. A cetek egy földalatti termet töltenek be, a csigák, puhányok, rovarok, lepkék pedig külön kisebb termeket töltenek be a homlokzat nagy helyiségei mögött. Igen érdekes és gazdag a paleontológiai gyüjtemény, hol gyönyörü mamuthok, dinotherium, Cervus giganteusok állnak. A foszil madarak a jobbszárny szeglet szobájában vannak elhelyezve, nevezetesebbek: a legrégibb madárnak kövülete, az Archeopterix macroura OwEN, mely Eichstadtban, Solenhofen mellett a palában találtatott (a külföldi Berlinben), a Hesperornis regalis, Ichtyornis victor, Dasornis londinensis, Argillonius longipennis, Odontopteryx toliapicus, Lithornis vulturinus, Gastornis parisiensis.

Gastornis klarsseni

Palaeortyx hoffmani

Struthio asiaticus

\footnotetext{
152 ma Muscicapa striata - szürke légykapó

${ }^{153}$ ma Aegithalos caudatus - öszapó

154 ma Coccothraustes coccothraustes - meggyvágó

${ }^{155}$ ma Anthus trivialis - erdei pityer

${ }^{156}$ ma Carduelis flavirostris - sárgacsőrü kenderike

${ }^{157}$ ma Carduelis spinus - csíz

158 ma Carduelis chloris - zöldike

${ }^{159}$ ma Carduelis carduelis - tengelic

${ }^{160}$ ma Sitta europaea caesia - csuszka közép-európai alfaja

${ }^{161}$ ma Cinclus cinclus - vízirigó

${ }^{162}$ ma Penguinus impennis - óriásalka
} 


\section{Leptoptilus (Argala) falconeri \\ Anas oeningensis \\ Harpagornis moorei \\ Dromornis \\ Aepyornis \\ Cnenuornis \\ Notornis \\ Aptornis \\ Dinornis elephatopus \\ Dinornis crassus \\ Dinornis giganteus \\ Dinornis didinus \\ Dinornis maximus \\ Dinornis didiformis \\ Diatryma gigantea \\ Gastornis.}

Mindezek csontvázrészletei, vagy egész vázai, utánzatai megvannak. Van 3 Aepyornis ${ }^{163}$ tojás is itt, Alca impennis ${ }^{164}$ tojás és csontváz szintén e gyüjteményben látható.

Ma délelött írtam anyámnak, majd kikocsiztunk DoRÁval a Hyde Parkba és az Oxfordstreetbe, hogy még egy képet kapjunk Londonról. Az élet a népes helyeken mindig nagyszerü. Elhaladtunk a kaszárnyák mellett, hol a szép scót uniformisban, gránátosokban gyönyörködtem, a királyi várt is láttuk még egyszer, s a sok angol coatokat ${ }^{165}$ piros kabátos trombitásával, a sok automatát, lovast, a kocsik különböző alakját, a tarka emeletes omnibusokat stb. 6 fényképfelvételt csináltam útközben. Végre még a Kensington Múzeumba mentünk, s átnéztem utoljára a madarakat és a paleontológiai gyüjteményt.

Ebéd tájt érkeztünk vissza. Szemem ma már jól volt, s így lunch ${ }^{166}$ után naplót írtam, majd olvastam, azután a csomagolást kezdtük meg, mely elég dolgot adott, mert sok holmink volt, s estig igénybe vett. Este LEWISsel felvételeimet előidőztük.

\section{Augusztus 27-én}

Szakadó esőre ébredtünk, s 9 órakor LEWIStől szívesen elbúcsúzva MAY-el a Victoria állomásra hajtottunk, de mivel a vonat csak 11 órakor indult, hát egyet kocsikáztunk a Trafalgar emlékhez, Westminsterhez. 11 órára ismét visszatértünk az állomásra, hol MAYtől is szívesen búcsút vettünk. Ezután a vonat a sok hirdetéstől görnyülő állomásból kirobogott, s 3/41 órára Doverbe vitt. Itt rögtön a készen álló gőzösre ültünk, melyen temérdek nép volt. Az idő meglehetősen tiszta volt, a tenger csak úgy középszerüen hullámzott, s így elég kedvező viszonyok közt búcsúztunk el Anglia kréta szikláitól. Alig hagytuk el a partot, már a franczia part is megjelent, s 1⁄1/2 órai tengeri út után - mely daczára hogy alig himbált a víz, sokakat tengeri beteggé tett - Calaisba értünk, hol a készen álló vonatra szálltunk. Kézi podgyászunkat a vámnál éppenséggel csak kívülről nézték meg, dohány és szeszes ital után kérdeztek, de bele nem tekintettek. Ebédet vásárolván elhelyezkedtünk a kényelmes elegáns vasúti kocsikban, s pár percz múlva robogtunk Francziaország belseje felé. A vonatról

\footnotetext{
163 elefántmadár, Madagaszkáron élt, mintegy 3 méter magas, 400 kg-os Aepyornis maximus, a legnagyobb valaha élt madárfaj volt, tojásának átmérője $33 \mathrm{~cm}$, ürtartalma 9 liter volt.

${ }^{164}$ ma Penguinus impennis - óriásalka

165 egyenruhásokat

166 ebéd
} 
lefényképeztem Calaist nagy világító tornyával. Gyorsan repített ezután tovább a gőzparipa Boulogne-ba, majd Etaplesbe, Abbeville-be, hol a tengert utolszor pillantottuk meg, s végbúcsút inténk neki. A szép időt eközben óriási fergeteg váltá föl, s egészen elsötétedett az ég, a szélvész pedig annyira felkerekedett, hogy egész gabna kazalokat forgatott. Amiensbe érvén az idő megjavult. Itt láttuk az első franczia katonákat és papokat. A vidék, melyet eddig láttunk, nagyon kedves volt, igen müvelt, sok gyárral behintett, szóval a cultura erős vonását hordozta magán. Clermont, Chantilly, Szt. Denis helyeket érintve, setétben érkeztünk a nagyszerü, villamosan kivilágított „Nord” pályaudvarra, hol nagy podgyászunkat igen felületesen pislantották meg a vámszemlén. Átesve azon, Grand Hotelba kocsiztunk a roppant élénk, fényes, kivilágított utczákon. A Grand Hotelban, e nagyszerü 600 szobás vendéglöben, a második emeleten igen jó szobát kaptunk, s a 3 fel-le járó liftek egyikén jutottunk oda. Átöltözködve vacsorázni mentünk, s azután nyugalomra.

\section{$\underline{\text { Augusztus 28-án }}$}

Megreggelizvén kocsira ültünk, s a városba egy körültekintő utat tettünk, miközben a párizsi élet hatalmas élénkségét, a város gyönyörüségeit közvetlen tapasztalásból ismertük meg. Legelöbb is a nagy Boulevardokon jártunk végig, látván a korinthusi oszlopokkal bővelkedő la Madeleine templomot, azután a Place de la Concorde gyönyörü terét a $22 \mathrm{~m}$ magas luksori ${ }^{167}$ obeliskkel, szökőkútjaival, s a szögletesen álló 6 allegorikus szoborcsoporttal, melyek Francziaország tartományait jelképezik. Ott van Elszasz-Lotharingia is, melyet a németek elfoglaltak, de le van fátyolozva, s fellobogózva, megkoszorúzva, egy fekete koszorú közepén a franczia színek, s rajta e szó "Spes". E hely borzalmas emlékü, s mai szépsége sem takarhatja el a történtét, mely nem felejti, el hogy itt hullott le XVI LAJOS, CORDAY SAROLTA és MARIA ANTOINETTE királyné feje a guillotin alatt, más 2800 fejjel együtt! Innét pillantottuk meg a világ legcsodálatosabb épületeinek egyikét, mely a legmagasabb emberi alkotmány, $\mathrm{s}$ egyszersmind a híres Eiffel tornyot. A Champs-Elysees hatalmas útján a toronyhoz kocsiztunk, s megnéztük az óriási kiállítási helyet, megmaradt épületeivel, melyek a Mars mezőn emelkednek, egyszersmind az Eiffel torony óriási, bámulatos szerkezetéröl is, közelebbi fogalmat szereztünk, láttuk a Trocadero palotát is, és visszajövet az Arc de Triomphe de l'Étoilere is vetettünk pillantást.

Elkocsiztunk ezután az operához, a Köztársaság szoborhoz, a bastille tér szobrához, a Louvrehoz, a Palais Royalhoz, a Tuilleriák Kertjéhez, s a nagy boulevardokon végig, miközben láttuk a Vendome szobrot, Porte St. Martin és Porte St. Denis kapukat. Azután a Notre Dameba mentünk NAGY KÁROLY lovasképét megnézni. E hatalmas kép, a gothikus építészet nagyszerüségével ható épületben, hol I. NAPÓLEON koronázta meg magát, megtekintettük a templom kincstárát is, remek, vagyonokat jelentő misemondó ruháival, szentség tartóival, oltár felszereléseivel, s bizony bizony felvetődött gondolataim közt a kérdés: nem e lenne üdvösebb a sok heverő tőke helyett a szegénységet pártolni, s e kincseket nem tartogatni, hanem helyettük értéküknek megfelelőleg segélyezni azokat, kik élnek, de élelmük után nem győznek járni, kik éheznek, rongyos ruhában járnak, s amellett épp oly emberek, mint az a III. NAPÓLEON, ki e drágaságok jórészét a nagylelküség érve alatt, valójában pedig azért adta az egyháznak, hogy az egyházi hatalmat is önző czéljainak megnyerje!

A Notre Dameból a Szajnán át a Képviselőház mellett az Invalidusok templomába siettünk, melynek óriási tere meglepett. Megnéztük itt I. NAPÓLEON sírját, mely igazán méltó e nagy alak emlékéhez. A sírbolt ajtaján áll végrendeletének e mondata: „Je désire que mes cendres reposent sur les bords de la Seine, au milieu de ce peuple français que j'ai tant aimé".

\footnotetext{
${ }^{167}$ luxori
} 
Innét még az Arc de Triomphe de l'Étoilehoz kocsiztunk, melynek tetejére (49.80 met. magas) 261 lépcsőn jutottunk fel. Tiszta verőfényes idő lévén, az egész Paris háztengerét beláthattuk. Nagyszerü benyomást hagyott bensőmben az itt összefutó 12 utcza, főleg a Neullyn át egyenesen a Tuilleriák Kertjéig vezető egyenes út, melyhez mérve a mi sugárutunkat, igazán csak egy harmadával ér fel. A kilátást velünk osztá egy szerecseny is. Ezután ebédre egyikébe a Grand Bouillon Parisienbe mentünk, mely fajta étkezőket DUVAL 1893-ban állítá fel. Itt nő szolgálat van, az étkezés jó. Ebéd után pár bevásárlást csináltunk, elmentünk a czukrászhoz a legelsőhöz - de meglepetésünkre fagylaltot itt nem kaptunk, mert csak házhoz készítenek, hanem a nápolyi kávéházba utasítottak, hol elég jó minőségü fagylalt volt. Pár órát lakásunkon pihenve ismét kocsira ültünk, s a kivilágított boulevardokon jártunk egyet. 9-kor vacsoráztunk szállónkban igen jól, azután lefeküdtünk.

\section{Augusztus 29-én}

Reggeli után kocsira ültünk, s a Jardin des plantesbe hajtottunk. Útközben egyszercsak felugrott a kocsira hátul egy 15 évesnek látszó suhancz, s közibünk hajolva egész kényelmesen helyezkedett el. DoRA megkérdezte mit akar? mire egészen nyugodtan azt felelte: „Így hamarább megyek”. Nem akarván scandalumot ${ }^{168}$ csinálni, hagytuk a kocsin, s miután jó darabot velünk jött, észrevétlen ismét leugrott. Igen jellemző a franczia köztársasági állapotokra! Különben nem csoda, hisz szemtelenségre hajlandó nép, köztársasági államformánál mindent megenged magának.

Furcsának tünik fel az is, mikor az ember a legtisztességesebb kávéházak előtt munkásokat, urakat, katonákat együtt ülni lát! A Jardin des plantesba érve végignéztem az állatkertet és a botanikai ültetvényeket, így az anatómiai épület nagy kitömött bálnáját, s azután a zoológiai épületbe siettünk, mely ugyan a nagyközönségnek nem volt nyitva, de minket beeresztettek. Magunk voltunk, így hát egész kényelmesen végig tekinthettünk a nagyszerü gyüjteményeken, mely a British Múzeum gazdagságával vetélkedik. Egészen új épületben, új elrendezésben van ez felállítva, s meglepő föleg azért, mert úgyszólván az egész állatvilág minden rendje, családja összefüggvén egy óriási oldalfolyosós teremben van kiállítva. A madárgyüjtemény igen gazdag, a példányok egész szépen vannak tömve, s minden fajból egész sorozatok vannak. Úgy látszik, itt bőrgyüjtemény nincs is, hanem minden fel van állítva, s a felállítottak száma mindesetre több mint a Kensington Múzeumban felállítottak száma. Igen gazdag és értékes a fészekgyüjtemény is. Biológiai csoportok azonban nincsenek.

Miután lefényképeztem az épületet, kocsink felé siettünk. (Az idő rövidsége miatt nem járhattuk be a többi gyüjteményeket.) Igen kielégítve hagytam el a múzeumot, s bár a kert jobban lehetne gondozott, a múzeum ellen éppen csak az a kifogás lehetne, hogy börgyüjtemény nincsen (ámbár lehet, hogy nem láttuk!), s hogy biológiai csoportok hiányoznak. E tekintetben a londoni sokkal korszerübb, s a tudomány mai kívánalmainak megfelelőbb.

Kocsira ülve a Pantheonhoz mentünk, útközben egy pár oly utczán haladva át, melyeken éjjel nem volna tanácsos egyedül botorkálni. A Pantheon nagyszerüsége igazán méltó ama nevezetes férfiak emlékéhez, kik itt örök álmaikat alusszák. Nincs ugyan hasonlatossága a Westminster Abbeyvel, de a maga nemében hatalmas épület, szép történeti festményekkel. Feltett kalappal járhatni benne, üressége még nagyobbá teszi, és nem sejteti velünk, hogy alattunk pihen: VICTOR HUGO, CARNOT, ROUDIN, LANNES marschall stb.

Aug. 30-án elutaztunk Párizsból, s Basel, Zürichen át tértünk Bécsbe és haza Kőszegre.

\section{$\Omega \Omega \Omega \Omega \Omega \Omega$}

${ }^{168}$ botrányt 


\section{4. ÉRTÉKELÉS}

CHERNEL ISTVÁN rendkívül céltudatos ember volt már fiatal korában is. Készült az ornitológusi hivatásra. Folyamatosan mélyítette tudását a terepen, illetve a hazai és a külföldi madárgyűjtemények tanulmányozása által egyaránt. Ezt a céltudatosságát, eredményeit és a Budapesten megrendezett II. Nemzetközi Madártani Congressus titkáraként végzett munkáját értékelte HERMAN OTTÓ, amikor CHERNELt javasolta az első teljesen magyar madártani összefoglaló munka megírására 1896-ban.

A három év alatt megvalósult 1017 oldalas mü (CHERNEL, 1899), a Magyarország madarai különös tekintettel gazdasági jelentőségökre előszavában CHERNEL részletesen beszámolt az előtanulmányokról, az adatgyüjtésről és a feldolgozásról. Jelen tanulmányunk szempontjából az alábbi leírás bír jelentőséggel:

„Bizonyos általános tanulságok kedvéért azután 1891 nyarán elmentem Norvégiába s bejártam ez országnak különösen a Jeges-tengerre dülö partvidékeit - a Nordkapot megkerülve Vadsőig, a Varanger-fjordban - egy álló hónapot töltve Tromsö szigetén is, a sarkköri madárélet vizsgálatával. Meglátogattam és tanulmányoztam a nagy európai múzeumokat, még pedig az ausztriaiak közül a bécsit és gráczit, a németországiak közül a drezdait, berlinit és hamburgit; azután a legnevezetesebb dániai, belgiumi és skandináviai madárgyüjteményeket s végre a londoni és párisi páratlan múzeumot."

Az észak- és nyugat-európai tanulmányutak szervezése során előnyét élvezte az 1891ben Budapesten szervezett II. Nemzetközi Madártani Congressus titkáraként megteremtett és ápolt kapcsolatainak. Így segítette norvégiai utazását ROBERT COLLETT (1842-1913) professzor Christianiából (ma Oslo) és RICHARD BOWDLER SHARPE (1847-1909), a British Múzeum (Kensington Múzeum) madárgyüjteményének kurátora is. E múzeumi vizsgálódásai során találkozott az ugyanott munkálkodó WILLIAM ROBERT OGILVIE-GRANT (1863-1924) skót ornitológussal, aki SHARPE után - 1909-1918 között - lett a British Múzeum madárgyüjteményének kurátora. CHERNELlel egy időben töltötte fél éves kutatási időszakát Londonban ERNST JOHANN OTTO HARTERT (1859-1933) német ornitológus (Frankfurt am Main) is, akivel ugyancsak többször konzultált. Érdemes tudni, hogy utóbbiak is részt vettek a budapesti ornitológiai kongresszuson (Horváth \& HERMAN, 1892).

SHARPE megmutatta, így tanulmányozhatta az európai madárkollekciót (föként bőrbe tömött madarakat), de amellett ALLAN OCTAVIAN HuME (1829-1912), az indiai madártan atyjának, a British Múzeumnak adományozott több mint 80000 példányos indiai gyüjteményét, valamint GODMAN, FREDERICK DUCANE (1834-1919) ugyancsak a British Múzeumnak ajándékozott (OSBERT SALVINNAL együtt gyüjtött és rendszerezett) középamerikai mintegy 520000 madárbőrt magába foglaló gyüjteményét.

Norvégiából Londonba utazva útközben megállt Brüsszelben is, ahol a Természetrajzi Múzeumban (ma az Institut royal des Sciences naturelles de Belgique) tanulmányozta a madarakat, illetve hazafelé tartva Londonból Párizsban, a Jardin des plantesban, ahol ugyancsak tanulmányozta a Természettudományi Múzeum (Muséum National d'Histoire Naturelle) madárgyüjteményét. A friss élmények lehetővé tették a londoni és párizsi gyüjtemények sommás összevetését is: „A [párizsi] madárgyüjtemény igen gazdag, a példányok egész szépen vannak tömve, s minden fajból egész sorozatok vannak. Úgy látszik, itt börgyüjtemény nincs is, hanem minden fel van állítva, s a felállítottak száma mindesetre több mint a Kensington Múzeumban felállitottak száma. Igen gazdag és értékes a fészekgyüjtemény is. Biológiai csoportok azonban nincsenek."

CHERNEL ISTVÁN és felesége észak- és nyugat-európai útjáról megállapíthatjuk, hogy az egy a nemzetközi madártan vérkeringésébe bekapcsolódott, azon körökben otthonosan mozgó, elfogadott szakember útja volt. Az út a következő időszakban meghozta a folyamatos 
kapcsolattartás, szakirodalom-csere személyes lehetőségét is (amit elmélyített az Ornithológiai Központ HERMAN OTTó általi létesítése, melynek CHERNEL alapító munkatársa volt, továbbá az 1893-ban alapított Aquila nemzetközi elismertsége is). Az út fontos és tudatos része volt CHERNEL jövőépítésének, hivatása kiteljesítésének, amely nagy műveihez, s végül - HERMAN OTTÓ halála után - az Ornithológiai Központ, illetve a Madártani Intézet vezetéséig emelte.

Végül a Svájcon át történő hazautazás céljáról CHERNEL IsTVÁN maga írt az Utazás Norvégia végvidékére (CHERNEL, 1893) címü könyvének befejező oldalain.

„Az utóbbi országot [Svájc] azért akartam érinteni, hogy a fris norvég benyomásokkal lássam s nyomban összehasonlithassam e két hegybirodalmat.

Az összemérésben - nézetem szerint - Norvégiát illeti az elsöbbség. Igaz, hogy Helvetia hegyei magasabbak, káprázatosabbak, vegetátiója - délibb fekvésénél fogva, - dúsabb, színpompásabb; de seholsem éreztem itt a nagyszerüség és fenség, azt a lebilincselö és mégis kedélyre is ható benyomását, mely az ember egész lényét megragadja. Az északi természet felséges komoly méltósága, a térbeli roppantság páratlan hatalma Norvégiában minden ponton nyilatkozik; valami sajátszerü szabadságérzet fog el, minden gondolatunk, érzelmünk, mintha szétterjengene, szárnyra szabadulna. A természet Norvégiában uralkodólag, legközvetlenebbül érinti kedélyünket, mert ösi tisztaságát, egyszerüségét a kultúra nem vetköztette még ki annyira, mint éppen Svájczban.

Norvégiában minden meg van, a mi ott meg van, s hozzá meg vannak, ami ott nincs: a tenger; az ezernyi csendes, páratlanul álló fjordok; a csodálatos, igazán bámulatot keltö halomszigetek; annyi szebbnél-szebb zuhatag, mint sehol a világon; s mindehhez - az éjféli nap."

Ezen gondolatokkal CHERNEL ISTVÁN emocionálisan is lezárta északi útját, amely sikeresen elégítette ki északon fészkelő vonuló madaraink élőhelyei, fészkelőhelyei iránti érdeklődését, egyszersmind lehetővé tette számára a madárvonulás okainak és teljességének megismerését.

\section{KÖSZÖNETNYILVÁNÍTÁS}

Köszönöm a Magyar Nemzeti Levéltár Vas Megyei Levéltárának, személy szerint Dr. TILCSIK GYÖRGY igazgató úrnak, hogy a naplót digitális formában, feldolgozásra rendelkezésemre bocsátotta. Köszönöm GOSZTONYI LíVIÁnak a napló rögzítése során végzett munkáját.

\section{IRODALOMJEGYZÉK}

CSABA J. (1963): Chernel István (Halálának 40. évfordulójára). Savaria 1: 49-56.

CHERNEL I. (1893): Utazás Norvégia végvidékére. A szerzői kiadása, Budapest. 449 p.

CHERNEL I. (1899): Magyarország madarai, különös tekintettel gazdasági jelentöségökre. III. Magyar Ornithologiai Központ, Budapest, 187+830 p.

Herman O. (1893): Az északi madárhegyek tájáról. K. M. Természettudományi Társulat, Budapest. $572 \mathrm{p}$.

Horváth G. \& HeRman O. (szerk.) (1892): Föjelentés. Második Nemzetközi Madártani Congressus. Budapest, 1891. I. Hivatalos rész. Magyar Királyi Tudomány-egyetemi Könyvnyomda, Budapest. 227 p. 
MAgYAR ORNITOLOGIAI KÖZPONT (1898): Nomenclator avium Regni Hungariae. Magyarország madárfajainak elnevezései. Franklin-Társulat, Budapest. 80 p.

MME NOMENCLATOR BIZOTTSÁG (2008): Magyarország madarainak névjegyzéke. Nomenclator avium Hungariae. Magyar Madártani és Természetvédelmi Egyesület, Budapest. 278 p.1 